\title{
A CLASSIFICATION OF THE PYRALIDAE, SUBFAMILY GALLERIANAE.
}

\author{
By SIR GEORGE F. HAMPSON, BARt., F.Z.S., Etc.
}

Pror ROBOSCIS well developed, short, or aborted and minute; palpi of male in the typical genera short, upturned and thickly scaled, hidden below the very large frontal tuft, in female downcurved and two or three times the length of head. In the more ancestral genera the palpi may be long and downcurved in both sexes, or rarely upturned; maxillary palpi small and filiform, or obsolete, sometimes more developed and somewhat dilated with scales, rarely long and two-jointed; frons usually with large tuft of hair; eye large, round; antennae usually almost simple, sometimes eiliated, in Sphinctocera with a small tooth at one-fifth, the basal joint often long, in Megarthria very long and curved; thorax and abdomen without crests; tibiae with all the spurs present. Forewing with the shape very variable; vein $1 a$ separate from $1 b ; 1 c$ absent; 4 sometimes absent or stalked with $5 ; 6$ sometimes stalked with $7,8,9 ; 7$ present ; 9 often and 8 and 10 rarely absent ; 10 from cell or sometimes stalked with 8,9 ; the male often has the cell very much produced, sometimes almost to termen, and with a glandular swelling containing masses of flocculent hair at base of costa on underside. Hindwing with the median nervure pectinated on upperside; veins $1 a, b, c$ present; 4 often and 3 rarely absent, 3 and 5 or 4,5 often stalked; the discocellulars often angled inwards almost to the base, rarely almost obsolete ; 6, 7 from cell or stalked, in Agdistopis 6 absent; 7 anastomosing with 8 or free; frenulum of female multiple.

The neuration is not very constant, and in the forewing of the same species vein 6 may be from the cell or stalked with $7,8,9 ; 7$ may be given off from 8 before or beyond 9 , and 10 may be rarely either present or absent; in the hindwing vein 4 is rarely either present or absent.

Larvae with all the prolegs present; in Galleria rather short and stout, in Aphomia longer and more cylindrical ; in Galleria and Achroia they live in the hives of bees, forming silken tubular galleries, in Aphomia in the nests of Vespa or Bombus, whilst some exotic species live in the nests of ants.

$\mathrm{A} \dagger$ before a reference means that the type is in the British Museum, and an * that the species is not in the collection.

In my opinion the name used for the subfamily and the genus Aphomia should be respectively Tineinae and Tinea Linn., but in deference to the wishes of the Editors of the Novitates I have here employed the terms Gallerianae and A phomia pending a more general consensus of the opinions of zoologists on the subject.

Two species have been claimed as the type of the genus, sociella the first on the list, a pellionella the twenty-first.

Linné's description of Tinea is "Alis convolutis, fere in cylindrum ; fronte prominula."

The first part of the description applies to the wings in repose, in sociella they are folded almost into a cylinder, in pellionella they are more tent-like in shape, with the apices of the forewings turned outwards; the second part applies 
설

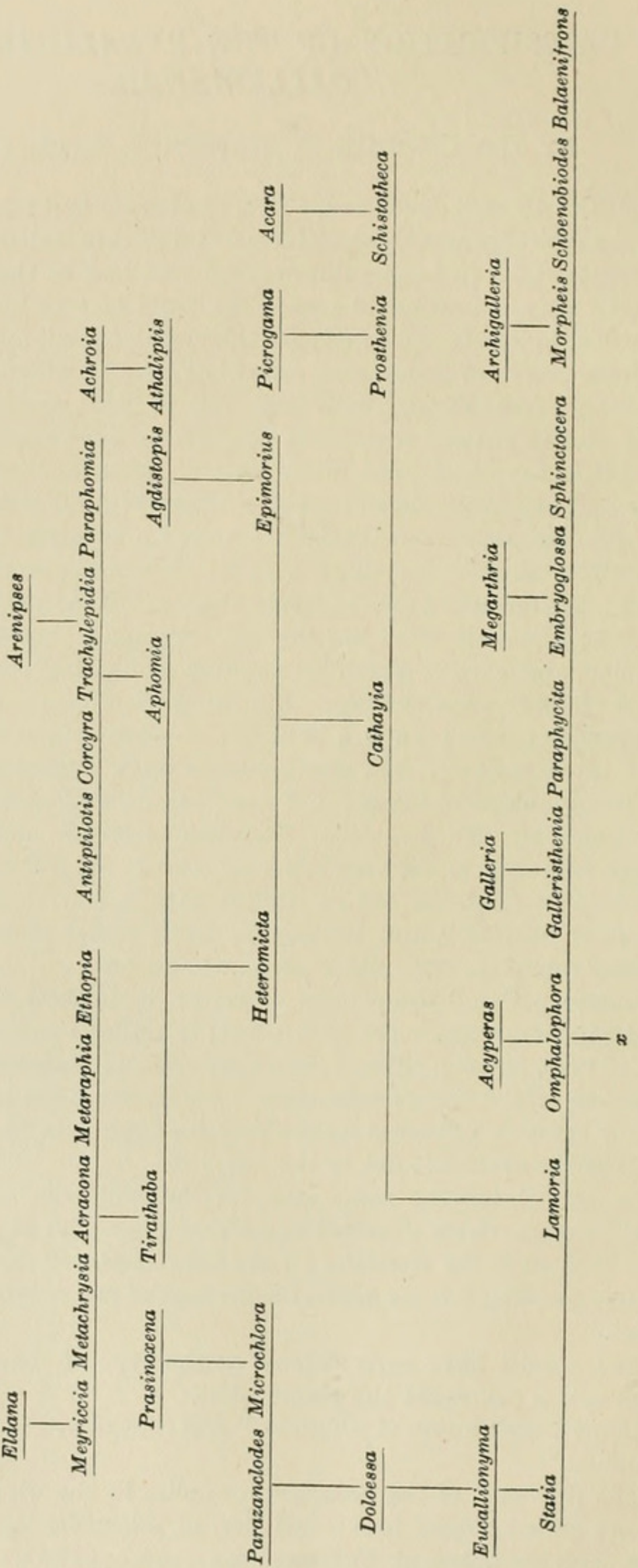


to the hair on the frons which in sociella forms a thick tuft, whilst in pellionella it consists of loose hair ; in fact sociella exactly answers the generic description, and pellionella does not.

The Latin word Trněa means a larval insect pest; it is used by Virgil for the worms of moths that live in bee-hives, by Horace for book-worms, and by other authors for those of clothes-moths, etc.

The type of a genus is the species from which the original author described that genus, and no action by a subsequent author or by all the Zoological Congresses in the world can alter that fact. The difficulty is to determine what that species is when the type is not indicated. The author would naturally put his type species down first on his list, but he might subsequently rearrange his list so as to get a more natural order of the species. Unless, however, there is any evidence of this, such as the first species not agreeing with the generic description, that species must be presumed to be the type.

Under Tortrix Linné states that the larvae twist leaves, uniting them by threads and living and feeding between them. The first species on his list, prasinana, therefore cannot be the type, and the second species, viridana, becomes the type.

The type of Sphinx is ligustri, because Linné in Faun. Succ. states that it is commonly called "The Sphinx" from the attitude of the larva. Similarly the type of Bombyx is mori because he calls it "The Bombyx," and the silkworm exclusively was known by that name to the Greeks and Romans.

Three methods are in use for determining the type of a genus when the type is not indicated.

1. The above, which is used in the revision of the Sphingidae by Rothschild and Jordan, the Catalogue of Lepidoptera Phalaenae in the British Museum, by most of the authors in Seitz' Macrolepidoptera, and by most American authors. It is the only method by which finality can be reached, and is rapidly coming into general use.

2. That the first reviser of a genus fixes the type of that genus. No two authors seem to agree exactly in their interpretation of this law, or as to what constitutes a revision, and whether a type has been fixed or not. Its chief advantage seems to be that each author can continue to use a generic name in the sense to which he is accustomed.

3 . That all species on the original list of a genus which have been used as the types of later genera shall be eliminated, and one of the remaining species be fixed as the type of the genus.

This led to so many anomalies, such as the least applicable species being fixed as the type of the genus, and even a species that the author of the genus had never seen, that it has fallen into disuse.

\section{KEY TO THE GENERA.}

A. Hindwing with veins 3,4 absent.

a. Forewing with vein 4 absent, $6,7,8$ stalked .

Paroxyptera, p. 27

b. Forewing with vein 4 present, 6 from the cell . Metachrysia, p. 30

B. Hindwing with vein 3 present, 4 absent.

a. Forewing with veins $6,7,8,9$ stalked.

$a^{1}$. Hindwing with the cell open

Arenipses, p. 36

$b^{1}$. Hindwing with the cell closed

Paraphomia, p. 37 
b. Forewing with vein 6 from the cell.

$a^{1}$. Forewing with vein 4 absent.

$a^{2}$. Forewing with vein 9 absent

Anerastidia, p. 27

$b^{2}$. Forewing with vein 9 present

Corcyra, p. 35

$b^{1}$. Forewing with vein 4 present.

$\mathrm{a}^{2}$. Forewing with vein 9 absent.

$\mathrm{a}^{3}$. Forewing with vein 11 becoming coincident with 12

Rhectophlebia, p. 27

$b^{3}$. Forewing with vein 11 free.

$a^{4}$. Forewing with veins 4,5 stalked

$a^{5}$. Frenulum absent; abdomen very long and tipuliform;

hind wing with vein 6 absent

$b^{5}$. Frenulum present; abdomen normal; hindwing with vein 6 present.

$a^{6}$. Forewing with vein 8 present ; hindwing with the cell open .

$b^{6}$. Forewing with vein 8 absent; hindwing with the cell closed .

$b^{4}$. Forewing with veins 4,5 from cell.

$a^{5}$. Frons with tuft of scales.

$a^{6}$. Forewing with vein 10 stalked with 7,8

$\mathrm{b}^{6}$. Forewing with vein 10 from the cell .

Agdistopis, p. 43

Stenachroia, p. 28

Phycitodes, p. 26

Metaraphia, p. 31

Eldana, p. 29

$b^{5}$. Frons without tuft of scales.

$a^{6}$. Hindwing with the apex produced and acute. . .

$b^{6}$. Hindwing with the apex not produced .

$b^{2}$. Forewing with vein 9 present.

$a^{3}$. Forewing with vein 7 from 8 beyond 9 . $a^{4}$. Forewing with vein 10 stalked with $7,8,9$.

$a^{5}$. Forewing with the cell long

Antiptilotis, p. 35

$b^{5}$. Forewing with the cell short.

$a^{6}$. Forewing with the apex produced and acute

Achroia, p. 44

Prasinoxena, p. 23

$b^{6}$. Forewing with the apex not produced.

$a^{7}$. Forewingshort, the termen straight

$b^{7}$. Forewing long, the termen rounded

Microchlora, p. 24

Trachylepidia, p. $: 6$ 
$b^{4}$. Forewing with vein 10 from the cell.

$a^{5}$. Forewing with the costa excised beyond middle, the apex falcate . .

$\mathrm{b}^{5}$. Forewing with the costa

Parazanclodes, p. 23 evenly arched.

$a^{6}$. Forewing with the apex rectangular. .

$b^{6}$. Forewing with the apex rounded .

$b^{3}$. Forewing with vein 7 from 8 before 9 . $a^{4}$. Forewing with vein 10 stalked with $7,8,9$. . . .

$b^{4}$. Forewing with vein 10 from the cell.

$a^{5}$. Forewing long and narrow. $a^{6}$. Forewing lanceolate, the apex produced and acute

Doloessa, p. 25

A phomia, p. 37

Athaliptis, p. 45

$b^{6}$. Forewing with the apex slightly produced.

$a^{7}$. Forewing with the costa strongly arched towards apex . .

$b^{7}$. Forewing with the costa slightly arched .

$b^{5}$. Forewing shorter and broader, the apex not produced . . .

C. Hindwing with vein 4 present.

a. Forewing with 10 stalked with $7,8,9$.

$\mathrm{a}^{1}$. Forewing with vein 7 from 8 beyond 9 .

$b^{1}$. Forewing with vein 7 from 8 before 9 or 9

Paraphycita, p. 54 absent.

$a^{2}$. Forewing with vein 3 from well before angle of cell

Cathayia, p. 46

$\mathrm{b}^{3}$. Forewing with vein 3 from close to angle of cell

Epimorius, p. 45

b. Forewing with veins $8,9,10$ stalked and 6,7 stalked;

frons with rounded prominence

Meyriccia, p. 29

Ethopia, p. 31

Tirathaba, p. 32

Heteromicta, $\ddagger$ p. 42

c. Forewing with vein 10 from the cell.

$\mathrm{a}^{1}$. Forewing with vein 9 absent; frons with conical prominence . . . . Archigalleria, p. 55

‡ In Heteromicta amydrastis the forewing sometimes has vein 7 from 8 beyond 9 , and in $H$. oodes vein 9 is sometimes absent. 
$b^{1}$. Forewing with vein 9 present; frons with large tuft of hair.

$\mathrm{a}^{2}$. Forewing with vein 7 from 8 beyond 9 . $a^{3}$. Forewing long and narrow.

$\mathrm{a}^{4}$. Forewing with the apex rectangular . . .

b4. Forewing with theapex rounded,

the termen very short . $\quad$. Prosthenia, p. 48

$b^{3}$. Forewing broader.

$a^{4}$. Forewing with thetermenexcised

$b^{4}$. Forewing with the termen not excised

Picrogama, p. 47

Galleria, p. 53

Acara, p. 49

$b^{2}$. Forewing with vein 7 from 8 before 9 .

$\mathrm{a}^{3}$. Palpi of male short, upturned.

$a^{4}$. Forewing with the discocellulars angled.

$\mathrm{a}^{5}$. Hindwing with veins 4,5 stalked.

$a^{6}$. Forewing with the apex produced and falcate

$b^{6}$. Forewing with the apex not produced.

$a^{?}$. Forewing very narrow . Picrogama (part), p. 47

$\mathrm{b}^{7}$. Forewing broad . Schistotheca, p. 49

$\mathrm{b}^{5}$. Hindwing with veins 4,5 from angle of cell .

Eucallionyma, p. 26

Statia, p. 26

$b^{4}$. Forewing with the discocellulars curved

Lamoria, $\ddagger$ p. 50

$b^{3}$. Palpi of male long and downcurved.

$a^{4}$. Forewing with the costa arched beyond middle then rather truncate towards apex which is produced and acute.

$a^{5}$. Palpi about the length of head and fringed with long hair below, the maxillary palpi dilated with scales. . .

Omphalophora, p. 52

$b^{5}$. Palpi about twice the length of head and moderately fringed with hair below, the maxillary palpi filiform

Acyperas, p. 52

$b^{4}$. Forewing with the costa evenly arched, the apex rounded; palpi about twice the length of head.

‡ In Lamoria inostentalis vein 4 of the hindwing is often absent. 


\author{
$a^{5}$. Antennae with the basal \\ jointvery long and curved \\ $b^{5}$. Antennae with the basal \\ joint short \\ $c^{4}$. Forewing with the costa slightly \\ excised beyond middle, the \\ apex rounded; palpi about \\ three times length of head . \\ $\mathrm{c}^{2}$. Forewing with vein 7 from the cell. \\ $a^{3}$. Frons with very large conical pro- \\ minence, grooved below; palpi \\ short and upturned . . . \\ $b^{3}$. Frons with conical prominence end- \\ ing in a small corneous beak; \\ palpi obliquely upturned; fore- \\ wing with veins 9 to 12 becoming \\ coincident below costa \\ $c^{3}$. Frons without prominence; palpi \\ porrect, about twice the length of \\ head
}

Megarthria, p. 54

Embryoglossa, p. 54

Sphinctocera, p. 55

Balaenifrons, p. 57

Morpheis, p. 56

Galleristhenia, p. 53

\section{Gen. Parazanclodes.}

Parazanclodes Hmpsn., Rom. Mém. viii. p. 490 (1901) . . . . . chrysaugella

Proboscis aborted ; palpi of male slight, upturned ; maxillary palpi minute ; frons with rather large tuft of hair; antennae short, the basal joint dilated; forewing narrow, the costa arched at base, then strongly excised, the apex produced and falcate, the termen strongly excised to middle; the cell two-thirds length of wing; vein 3 from well before angle of cell ; 4 and 5 well separated; 6 from upper angle; $7,8,9$ stalked, 7 from beyond $9 ; 10,11$ from cell ; the male with large glandular swelling at base of costa on underside fringed with long hair, the cell clothed with fine hair, a patch of androconia below the cell before base of vein 2. Hindwing with vein 2 from before angle of cell; 3 and 5 from angle; 4 absent ; 6,7 stalked, 7 anastomosing with 8 ; the male with patch of androconia in lower extremity of cell on upper side.

\section{* Parazanclodes chrysaugella.}

Parazanclodes chrysaugella Hmpsn., Rom. Mém. viii. p. 490. pl. 53. f. 18 (1901).

\section{Br. N. Guinea.}

\section{Gen. Prasinoxena.}

Prasinoxena Meyr., Trans. Ent. Soc. 1894. p. 479

Type.

monospila

Proboscis slight; palpi of male minute, upturned, of female porrect and extending about the length of head; maxillary palpi slight; frons without tuft of hair ; antennae short, the basal joint somewhat long and dilated. Forewing rather short and broad, the costa rather oblique towards apex which is produced and pointed, the termen oblique; the cell long; vein 2 from middle of cell ; 3, 4, 5 from angle ; 6 from just below upper angle; 7,8 , and 10 stalked, 7 from beyond 10,9 absent ; 11 from cell ; the male with slight glandular swell- 
ing at base of costa. Hindwing with the cell open; veins 3 and 5 stalked to near termen, 4 absent ; 7 anastomosing with 8 ; the male with a fold on inner margin containing a tuft of long hair.

Sect. I. Forewing of male on underside with fringe of hair along median nervure to just beyond the cell, downturned above the nervure and upturned below it.

\section{(1) Prasinoxena metaleuca.}

$\dagger$ Prasinoxena metaleuca Hmpsn., J. Bomb. Nat. Hist. Soc. xxi. p. 1249. pl. G. f. 28 (1912).

Ceylon.

Sect. II. Forewing of male on underside with a streak of hairy scales above median nervure.

\section{(2) Prasinoxena monospila.}

† Prasinoxena monospila Meyr., Trans. Ent. Soc. 1894. p. 480; Hmpsn., Rom. Mém. viii. p. 499. pl. 54. f. 14.

\section{Borneo ; Pulo Laut.}

Sect. III. Forewing of male on underside normal.

(3) Prasinoxena bilineella.

Prasinoxena bilineella Hmpsn., Rom. Mém. viii. p. 500. pl. 54. f. 17 (1901).

Amboina ; Batchian.

(4) Prasinoxena viridissima.

$\dagger$ Prasinoxena viridissima Swinh., Fasic. Malay. Zool. i. p. 98 (1903).

Selangore.

(5) Prasinoxena hemisema.

† Prasinoxena hemisema Meyr., Trans. Ent. Soc. 1894. p. 480; Hmpsn., Rom. Mém. viii. p. 500. pl. 54. f. 15.

Pulo Laut; Sumbawa.

\section{GEN. Microchlora.}

Microchlora Hmpsn., Rom. Mém. viii. p. 468 (1901) . . . . . . eariasella

Proboscis slight; palpi of male short, upturned; maxillary palpi minute ; frons without tuft of hair ; antennae with the basal joint long and dilated. Forewing short and broad, the apex rectangular, the termen straight; the cell rather short; vein 2 from middle of cell ; $3,4,5$ well separated ; 6 from upper angle; 7, 8, 9, 10 stalked, 7 from beyond 9 ; 11 from cell. Hindwing with the cell short; vein 2 from near angle of cell; 3 and 5 stalked, 4 absent; the discocellulars angled; 6,7 from upper angle, 7 anastomosing with 8 ; the male with fold on inner area containing a tuft of long hair.

\section{(1) Microchlora eariasella.}

Microchlora eariasella Hmpsn., Rom. Mém. viii. p. 468. pl. 54. f. 13 (1901).

Batchian ; Celebes. 
(2) † Microchlora bilineella n. sp.

c. Head and thorax emerald-green; pectus, legs and abdomen whitish. Forewing emerald-green, an erect slightly waved black and whitish antemedial line from subcostal nervure to inner margin, a white point before it in submedian fold ; a slightly waved black and whitish postmedial line from below costa to inner margin, excurved to vein 4 then rather oblique, a white point beyond it below vein 4 ; the costa towards apex, termen and cilia red-brown and whitish with a series of white points defining the green area. Hindwing white. Underside of forewing and the costal area of hindwing green.

Solomon Is., Bougainville (Meek), 1 ơ type. Exp. 20 mill.

\section{Gen. Doloessa.}

Doloessa Zell., Isis. 1848. p. 860

Type.

Thagora Wlk., xxviii. 205 (1863)

Proboscis fully developed; palpi of male very short, upturned, thickly scaled, of female porrect and extendin ${ }_{\circ}$ about the length of head ; maxillary palpi filiform; frons with large tuft of hair above; antennae of male almost simple, the basal joint with tuft of hair below. Forewing rather narrow, the apex rectangular, the termen evenly curved; veins 3 and 5 from close to angle of cell ; 6 from upper angle ; 7, 8, 9 stalked, 7 from beyond $9 ; 10,11$ from cell. Hindwing with vein 2 from close to angle of cell; 3 and 5 strongly stalked, 4 absent; the discocellulars angled to near base; 6,7 stalked, 7 anastomosing with 8 .

Sect. I. Forewing of male on underside with the cell and the area just below and beyond its extremity clothed with black androconia ; hindwing on upperside with the costal area clothed with black androconia to beyond middle.

(1) Doloessa hilaropis.

Melissoblaptes hilaropis Meyr., Trans. Ent. Soc. 1897. p. 378.

Doloessa plumbolineella Hmpsn., Rom. Mém. viii. p. 488. pl. 54. f. 10 (1901).

Queensland.

(2) Doloessa castanella.

$\dagger$ Thagora castanella Hmpsn., Moths Ind. iv. p. 4 (1896); id., Rom. Mém. viii. p. 488.

Garcinoptera ochrociliella Rag., Rom. Mém. viii. pl. 8. f. 24 (1893) non descr.

Ceylon; Andamans ; Christmas I. ; Tenimber.

Sect. II. Wings of male without patches of androconia.

(3) Doloessa constellata.

† Doloessa constellata Hmpsn., J. Bomb. Nat. Hist. Soc. xii. p. 94 (1901); id., Rom. Mém. viii. p. 489. pl. 54. f. 12 .

Assam, Khásis.

(4) Doloessa viridis.

Doloessa viridis Zell., Isis. 1848. p. 860 ; Rag., Rom. Mém. viii. p. 489. pl. 46. f. 16.

$\dagger$ Thagora figurana Wlk., xxvii. 205 (1863); Hmpsn., Ill. Het. B. M. ix. pl. 157. f. 8; id., Moths Ind. iv. p. 5.

Tyana ornata Wileman, Entom. xliii. p. 291 (1910).

Formosa ; Ceylon ; Philippines; Java ; Kei Is.; N. Guinea ; Solomon Is. ; Queensland. 


\section{Gen. Eucallionyma.}

Callionyma Meyr., Proc. Linn. Soc. N.S.W. vii. p. 161 (1882), nec Callionymus Linn., Pisces (1758)

Eucallionyma Rag., Rom. Mém. viii. p. 430 (1901)

Type.

sarcodes sarcodes

Proboscis slight; palpi of male short, upturned, thickly scaled, of female downcurved ; frons with large tuft of hair; antennae of male almost simple, the basal joint somewhat dilated. Forewing with the costa moderately arched, the apex produced and somewhat falcate, the termen obliquely curved; the lower angle of cell produced; vein 3 from near angle; 5 from above angle ; the discocellulars angled inwards; vein 6 from upper angle; 7, 8, 9 stalked, 7 from before $9 ; 10,11$ from cell ; the male with large fold on basal half of costa on underside containing masses of flocculent hair. Hindwing with vein 3 from angle of cell ; 4, 5 stalked; the discocellulars angled inwards to rather near base ; 6,7 stalked, 7 anastomosing with 8 .

\section{Eucallionyma sarcodes.}

Callionyma sarcodes Meyr., Proc. Linn. Soc. N.S.W. vii. p. 161 (1882); Rag., Rom. Mém. viii. p. 431. pl. 53. f. 7 .

N.S. Wales; Victoria.

Gen. Statia.

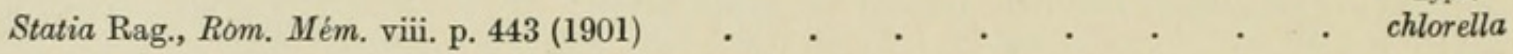

Proboscis strong, short; palpi of female slender, the second joint oblique to just beyond the frons, the third minute, porrect, acuminate at tip ; antennae short, ciliated. Forewing with the costa arched, the apex somewhat produced, the termen evenly curved; vein 3 from near angle of cell ; 4 , 5 separate; the discocellulars strongly angled inwards, 6 shortly stalked with $7,8,9 ; 7$ from before $9 ; 10,11$ from cell. Hindwing with the lower angle of cell much produced; vein 3 from before angle; 4, 5 from angle; the discocellulars strongly angled inwards; 6,7 strongly stalked, 7 anastomosing. with 8 .

\section{* Statia chlorella.}

Statia chlorella Rag., Rom. Mém. viii. p. 444. pl. 45. f. 14 (1901).

Peru.

\section{Gen. Phycitodes nov.}

Type P. albistriata.

Proboscis fully developed; palpi of female very short, porrect and not reaching as far as the large frontal tuft of hair; maxillary palpi invisible; antennae rather long, with slight tufts of scales at the joints. Forewing long and narrow, the apex rounded, the termen obliquely curved; vein 2 from towards angle of cell; 3 from before angle ; 4,5 stalked ; 6 from upper angle ; 7 from before angle ; 8,9 absent ; 10,11 from cell ; a fringe of scales below base of costa on underside. Hindwing with the cell about one-third length of wing; vein 2 from towards angle ; 3 from angle; 5 from just above angle, 4 absent ; the discocellulars curved ; 6,7 from upper angle of cell ; 7 anastomosing with 8 . 
$\dagger$ Phycitodes albistriata n. sp.

․ Head, thorax and abdomen reddish brown mixed with white; forewing whitish tinged and thickly irrorated with dark purplish brown; white fasciae on basal half of eosta, in lower part of cell and on median nervure, and streaks on the veins beyond the cell; slight dark spots in upper and lower angles of cell and a terminal series of points; a faint brown antemedial line, excurved in the cell then oblique, and faint rather diffused oblique postmedial line. Hindwing ochreous white tinged with reddish brown, especially on costal area; a terminal brown line; cilia white with a brown line near base. Underside more suffused with brown.

Br. E. Africa, N'dimu (Betton), 1 q type. Exp. 36 mill.

\section{Gen. Rhectophlebia.}

Rhectophlebia Rag., Nouv. Gen. p. 52 (1888)

Type. monilella

Proboscis small; palpi of female downcurved, extending about three times length of head, the second joint thickly scaled, the third short; maxillary palpi absent; frons with large tuft of hair; antennae ciliated. Forewing rather narrow, the apex rounded, the termen evenly curved; vein 2 from near angle of cell ; 3 from angle ; 4, 5 strongly stalked ; 6 from upper angle ; 7, 8 stalked, 9 absent; 10, 11 from cell, 11 becoming coincident with 12 . Hindwing with the cell very short; veins 3 and 5 stalked, 4 absent; 6,7 from upper angle, 7 anastomosing with 8 .

\section{* Rhectophlebia monilella.}

Rhectophlebia monilella Rag., Nouv. Gen. p. 52 (1888); id., Rom. Mém. viii. p. 493. pl. 8. f. 23.

\section{Colombia.}

\section{Gen. Paroxyptera.}

Paroxyptera Rag., Rom. Mém. viii. p. 503 (1901)

Proboscis small; palpi short, oblique, the third joint very short, porrect; maxillary palpi obsolete; frons with strong tuft of hair; antennae of female minutely serrate, the basal joint with tuft of hair on inner side. Forewing narrow, the apex produced, the termen very oblique; veins 3 and 5 from angle of cell, 4 absent ; 6, 7, 8 stalked, 9 absent; 10, 11 from cell. Hindwing with veins 2 and 5 from angle of cell, 3, 4 absent; 6, 7 from upper angle, 7 anastomosing with 8 .

\section{* Paroxyptera filiella.}

Achroea filiella Saalm., Ber. Senck. Ges. 1879. p. 308; Rag., Rom. Mém. viii. p. 503. pl. 45. f. 4. Madagascar.

\section{GEn. Anerastidia.}

Anerastidia Hmpsn., Rom. Mém. viii. p. 500 (1901) Type.

Proboscis slight; palpi of male short, upturned, fringed with hair, of female downcurved and extending about the length of head; maxillary palpi minute ; frons with a large tuft of hair; antennae short, the basal joint long and tufted 
with hair in front. Forewing long and narrow, the apex rounded, the termen oblique ; the cell long ; vein 2 from middle of cell ; 3 and 5 from angle, 4 absent ; the discocellulars curved; vein 6 from upper angle; 7,8 stalked, 9 absent; 10,11 from cell; the male with small glandular swelling and tuft of hair at base of costa on underside. Hindwing with vein 2 from angle of cell ; 3 and 5 stalked, 4 absent ; the discocellulars retracted almost to base; veins 6,7 from upper angle, 7 anastomosing with 8 .

\section{(1) Anerastidia rhodoneura.}

Anerastia rhodoneura Turner, Pr. R. Soc. Queensl. xix. p. 43 (1905).

Queensland, Thursday I.

\section{(2) Anerastidia albivittella.}

$\dagger$ Anerastidia albivittella Hmpsn., Rom. Mém. viii. p. 500. pl. 54. f. 22 (1901).

Hypsotropha bipunctella Wileman, Trans. Ent. Soc. 1911. p. 356.

Japan; Borneo; Pulo Laut; Amboina.

(3) $†$ Anerastidia pulverea n. sp.

๙. Head and thorax white faintly tinged with brown; abdomen white, the second and third segments dorsally tinged with ochreous. Forewing white faintly tinged with red-brown and irrorated with a few dark scales; an oblique subterminal series of slight blackish marks in the interspaces; a terminal series of black points. Hindwing semihyaline white, the veins and termen tinged with ochreous.

ㅇ. Thorax irrorated with blackish scales; forewing thickly irrorated with blackish scales, a diffused antemedial black mark above inner margin, the subterminal spots and terminal points more distinct; hindwing with the termen tinged with brown towards apex.

Argentina, Gran Chaco, Florenzia (Wagner), 1 ơ type, Sta. Fé, Ocampo (Wagner), 1 ㅇ. Exp. 22 mill.

\section{(4) * Anerastidia ebenopasta.}

Anerastidia ebenopasta Turner, $\operatorname{Pr}$. R. Soc. Queensl. xviii. p. 122 (1904).

Queensland.

\section{GEN. Stenachroia.}

Stenachroia Hmpsn., J. Bomb. Nat. Hist. Soc. xii. p. 93 (1901) . _ _ . . . elongella

Proboscis fully developed; palpi of male small, upturned, thickly scaled, of female downcurved, extending about twice the length of head; frons with large tuft of hair; antennae short, the basal joint long and with tuft of hair below. Forewing very long and narrow, the apex rounded, the termen obliquely curved; vein 2 from middle of cell; 3 from angle; 4,5 strongly stalked ; 6 from upper angle ; 7, 8 stalked from before angle, 9 absent ; 10,11 from cell ; the male with glandular swelling at base of costa on underside and fringe of upturned hair from middle of median nervure. Hindwing with the cell open; veins 3 and 5 stalked, 4 absent ; 6, 7 from upper angle, 7 anastomosing with 8 . 
(1) Stenachroia elongella.

† Stenachroia elongella Hmpsn., J. Bomb. Nat. Hist. Soc. xii. p. 93 (1901); id., Rom. Mém. viii. p. 494. pl. 54. f. 20.

Assam, Khasis ; Bengal, Pusa ; Ceylon.

(2) * Stenachroia myrmecophila.

Stenachroia myrmecophila Turner, Pr. R. Soc. Queensl. xix. p. 54 (1905).

Queensland.

Gen. Eldana.

Eldana Wlk., xxxii. 632 (1865)

Type.

saccharina

Proboscis slight; palpi of male short and upturned, of female downcurved and extending about the length of head; maxillary palpi minute; frons with tuft of scales; antennae short, the basal joint long and dilated. Forewing long and narrow, the costa slightly arched, the apex rounded, the termen evenly curved ; vein 2 from middle of cell ; 3 from well before angle ; 4, 5 from angle ; 6 from upper angle; 7,8 stalked from before angle, 9 absent ; 10, 11 from cell; the male with slight glandular swelling at base of costa on underside. Hindwing with vein 2 from near angle of cell; 3 and 5 stalked, 4 absent; the discocellular angled inwards to near base; veins 6,7 from upper angle, 7 anastomosing with 8 .

\section{(1) * Eldana leucostictalis.}

Eldana leucostictalis Lower, Tr. R. Soc. S. Austr. 1903. p. 50.

Queensland.

(2) Eldana saccharina.

† Eldana saccharina Wlk., xxxii. 633 (1865) ; Hmpsn., Rom. Mém. viii. p. 495. pl. 45. f. 18.

Sierra Leone; Gold Coast; Mozambique.

\section{Gen. Meyriccia.}

Meyrickia Rag., Rom. Mém. viii. p. 456 (1901) .

Proboscis fully developed ; palpi of male short, upturned, of female downcurved and extending about twice the length of head; maxillary palpi tufted with hair ; frons smooth, with large tuft of hair above ; antennae short, almost simple. Forewing very long and narrow, the apex rounded, the termen obliquely curved; the cell about three-fourths length of wing; vein 3 from well before angle; 4, 5 from angle; the discocellulars angled; 6 from just below upper angle; $7,8,9$ stalked, 7 from before $9 ; 10,11$ from cell; male with small glandular swelling at base of costa on underside and the cell clothed with silky hair. Hindwing with vein 2 from close to angle of cell; 3 and 5 stalked, 4 absent; the discocellulars angled inwards almost to base; 6, 7 from upper angle, 7 anastomosing with 8 .

\section{Meyriccia latro.}

$\dagger$ Melissoblaptes latro Zell., Verh. zool.-bot. Ges. Wien. 1873. p. 213; Rag., Rom. Mém. viii. p. 457. pl. 46. f. 8.

N. S. Wales; s. Australia ; w. Australia. 


\section{Gen. Metachrysia.}

Metachrysia Hmpsn., Rom. Mém. viii. p. 504 (1901)

Type.

acyperella

Proboscis small ; palpi slender, upturned, fringed with hair ; maxillary palpi very small ; frons with small tuft of hair; antennae of male short. Forewing narrow, the costa arched before apex which is obliquely truncate and produced to a point, the termen oblique; the cell very long, the lower angle produced; veins 2, 3, 4, 5 given off at equal distances and parallel ; the discocellulars very oblique ; vein 6 from upper angle of cell ; 7, 8 stalked, 9 absent ; 10,11 from cell ; the male on underside with the cell clothed with fine silky hair, with a small glandular swelling at base of costa. Hindwing with the cell open; veins 2 and 5 stalked, 3,4 absent ; 6,7 stalked, 7 anastomosing with 8 .

\section{* Metachrysia acyperella.}

Metachrysia acyperella Hmpsn., Rom. Mém. viii. p. 504. pl. 53. f. 17 (1901).

D'Entrecasteaux Is., Fergusson I.

\section{Gen. Acracona.}

Acracona

Palpi of male minute, of female reaching just beyond the large frontal tuft; maxillary palpi small; antennae with the basal joint long, the shaft of moderate length ciliated ; fore and mid tibiae and tarsi thickened and flattened especially in female. Forewing with the costa arched at base, the apex strongly produced and acute; the cell rather short; vein 3 from near angle of cell; 4, 5 from angle; the discocellulars curved; 6 from below upper angle; 7, 8, 9, 10 stalked, 7 from beyond $9 ; 11$ free; male with a large glandular swelling enclosing flocculent hair on underside of basal costal area and a fringe of long upwardly directed hair in submedian fold at middle. Hindwing with veins 3 and 5 from angle of cell, 4 absent ; the discocellulars angled inwards; 6, 7 from upper angle, 7 anastomosing with 8 .

\section{(1) * Acracona flammealis n. sp.}

Head and thorax purplish red; abdomen orange-red. Forewing purplish red irrorated with darker scales; an indistinct discoidal spot; cilia orange. Hindwing orange-red.

S. Nigeria, Warri (Roth.), type in coll. Rothschild. Exp. ơ 28, 우 36 mill.

\section{(2) † Acracona metachryseis n. sp.}

․ Head, thorax, abdomen and forewing rufous with a greyish tinge, the last slightly irrorated with fuscous and with a fuscous discoidal spot; cilia orange. Hindwing golden orange. Underside orange except costal area of both wings.

Sierra Leone (Clements), 1 ㅇ type. Exp. 42 mill.

\section{(3) * Acracona remipedalis.}

Acracona remipedalis Karsch, Ent. Nachr. xxvi. p. 245 (1900).

Togoland. 
Gen. Metaraphia.

Metaraphia Hmpsn., Rom. Mém. viii. p. 494 (1901) .

Proboscis slight; palpi of female short, porrect, typically not extending as far as the frontal tuft which is large and truncate; antennae short, the basal joint long and curved. Forewing long and narrow, the costa slightly arched, the apex typically acute, the termen evenly curved; the cell long; vein 2 from middle of cell; 3 from well before angle; 4,5 from angle; the discocellulars angled ; 6 from upper angle; 7,8 and 10 stalked, 7 from beyond 10,9 absent ; 11 from cell ; a small glandular swelling at base of costa on underside. Hindwing with the apex typically produced and acute; vein 2 from near angle of cell ; 3 and 5 stalked, 4 absent ; the discocellulars strongly angled ; 6, 7 from upper angle, 7 anastomosing with 8 .

Sect. I. Both wings with the apex produced and acute; forewing with vein 2 from middle of cell; palpi not extending as far as the frontal tuft.

\section{(1) Metaraphia postluteella.}

† Metaraphia postluteella Hmpsn., Rom. Mém. viii. p. 495. pl. 55. f. 2 (1901).

Borneo, Baram.

Sect. II. Both wings with the apex rounded; forewing with vein 3 from near angle of cell; palpi extending about the length of head.

(2) † Metaraphia calamistis n. sp.

q. Head, thorax and abdomen ochreous tinged with rufous, especially on dorsum of abdomen. Forewing ochreous irrorated with black-brown especially along median nervure; a diffused antemedial blackish mark on vein 1 and terminal series of points. Hindwing ochreous, the termen brownish. Underside with the forewing and costal area of hindwing irrorated with brown.

w. Colombia, San Antonio (Palmer), 1 o type. Exp. 28 mill.

Gen. Ethopia.

Ethopia Wlk., xxxi. 233 (1863)

Type.

roseilinea

Proboscis fully developed; palpi of male short, upturned, thickly scaled, of female obliquely upturned, the second joint reaching to about middle of frons, the third long, smoothly scaled; maxillary palpi slight; frons with tuft of hair ; antennae short, almost simple; male with large protrusible genital tuft. Forewing narrow, the costa highly arched throughout in female, towards apex only in male, the apex rounded, the termen obliquely curved, the inner margin somewhat excised towards tornus ; male with vein 3 from just before angle of cell ; 4 from angle with a recurrent vein running back from it to middle of subcostal nervure; vein 5 from middle of cell from the almost obsolete discocellulars which are strongly angled inwards above it ; 6 from upper angle ; 7, 8, 9 stalked, 7 from before $9 ; 10,11$ from cell ; the cell on underside clothed with silky downturned hair; female with veins 4, 5 from angle of cell and the discocellulars strongly angled inwards. Hindwing with veins 3 and 5 from angle of cell, 4 absent ; the discocellulars angled inwards to near base ; 6,7 strongly stalked and anastomosing with 8 ; the male with fringe of long downturned hair on upperside from beyond upper angle of cell. 


\section{Ethopia roseilinea.}

Ethopia roseilinea Wlk., xxxi. 233 (1863) ; Swinh., Cat. Het. Mus. Oxon. ii. pl. vii. f. 4; Hmpsn., Rom. Mém. viii. p. 458. pl. 53. f. 6.

Crambomorpha aurora Voll., Tijd. v. Ent. xvi. p. 246. pl. 12. f. 2 (1873).

Philippines, Mindanão; Salawati; Dutch N. Guinea; D'Entrecasteaux Is., Fergusson I.

\section{GEN. Tirathaba.}

Tirathaba Wlk., xxx. 961 (1864)

Mucialla Wlk., xxxv. 1739 (1866) .

Harpagoneura Butl., A. M. N. H. (5). xv. p. 242 (1885)

Coleoneura Rag., Nouv. Gen. p. 52 (1888) .

Type.

mundella

mundella

complexa

trichogramma

Proboscis fully developed; palpi of male short, upturned, thickly scaled, of female downcurved and extending about twice the length of head; maxillary palpi slight; frons with tuft of hair ; antennae short and almost simple. Forewing narrow, the apex slightly produced, the termen evenly curved; the cell in male typically about two-thirds length of wing; vein 3 from just before angle of cell ; 4 from angle; 5 typically from well above angle; the discocellulars angled inwards ; 6 from below upper angle ; 7, 8, 9 stalked, 7 from before 9 ; 10 , 11 from cell ; the male typically with small glandular swelling at base of costa on underside and the cell clothed with silky androconia; female with vein 3 typically from near angle of cell and 4, 5 strongly stalked. Hindwing with veins 3 and 5 from angle of cell or stalked, 4 absent; the discocellulars angled inwards to near base ; 6, 7 from upper angle, 7 touching 8 at a point ; the male with fringe of hair from below basal part of costa on upperside.

Sect. I. (Harpagoneura). Forewing of male with an elongate brand beyond upper angle of cell, the subcostal neuration and terminal area distorted; the cell extending to about three-fourths of wing.

\section{(1) Tirathaba acrocausta.}

$\dagger$ Harpagoneura acrocausta Meyr., Trans. Ent. Soc. 1897. p. 79 ; Hmpsn., Rom. Mém. viii. p. 466. pl. 54. f. 9.

Mucialla fuscolimbalis Snell., Tïd. v. Ent. xliii. p. 308. pl. 17. ff. 10. 11 (1900).

Philippines ; Java ; Celebes, Sangir I. ; D'Entrecasteanx Is., Fergusson I. ; Louisiade Is., St. Aignan; Queensland, Cedar Bay.

\section{(2) Tirathaba trichogramma.}

Heteromicta trichogramma Meyr., Trans. Ent. Soc. 1886. p. 273 ; Rag., Rom. Mém. viii. p. 461. pl. 51. f. 13.

Coleoneura tacanovella Rag., Nouv. Gen. p. 52 (1888).

Fiji. The larva eats into young coconuts.

(3) Tirathaba complexa.

$\dagger$ Harpagoneura complexa Butl., A. M.N.H. (5). xv. p. 242 (1885) ; Rag., Rom. Mém. viii. p. 465. pl. 54. f. 7. 
(4) * Tirathaba irrufatella.

Tirathaba irrufatella Rag., Rom. Mém. viii. p. 462. pl. 43. f. 26 (1901).

Japan.

Sect. II. Forewing of male without brand beyond upper angle of cell, the subcostal neuration and terminal area not distorted.

A. Forewing of male with the cell extending almost to termen.

(5) †Tirathaba pseudocomplana n. n.

Harpagoneura complana Hmpsn., Rom. Mém. viii. p. 466. pl. 46. f. 13 (nec Feld).

Br. N. Guinea, Aroa R. ; D'Entrecasteaux Is., Fergusson I. ; Solomon Is., Florida I. ; Queensland, Geralton.

B. Forewing with the cell extending to about two-thirds of wing.

a. (Tirathaba). Forewing of female with veins 4, 5 strongly stalked.

(6) Tirathaba mundella.

$\dagger$ Tirathaba mundella Wlk., xxx. 961 (1864).

$\dagger$ Mucialla mundella Wlk., xxxv. 1739 (1866).

Borneo, Sarawak.

b. Forewing of female with veins 4, 5 from cell or shortly stalked.

$a^{1}$. Forewing of male on underside with glandular swelling below base of costa and the cell clothed with silky androconia.

(7) † Tirathaba ignivena n. sp.

․ Head and thorax brownish grey tinged with purplish red; abdomen orange-yellow; pectus and legs whitish irrorated with red-brown; ventral surface of abdomen yellowish white. Forewing pale grey-brown, the basal and costal areas irrorated with a few black scales; the veins below costa with rather diffused purplish-red streaks, the other veins and inner margin with well-defined fiery-red streaks; a fine black terminal line interrupted by white points ; cilia red-brown with blackish marks near base. Hindwing orange-yellow. Underside of forewing yellow with a brownish tinge.

Iouisiade Is., St. Aignan, 1 q type. Exp. 36 mill.

(8) Tirathaba rufivena.

$\dagger$ Lamoria rufivena Wlk., xxx. 960 (1864); Hmpsn., Moths Ind. iv. p. 5; id., Rom. Mém. viii. p. 460. pl. 46. f. 7 .

Lamoria ruptilinea Wlk., xxxv. 1723 (1866).

Melissoblaptes rufovenalis Snell., Tijd. v. Ent. xxiii. p. 248 (1879) ; id., xxvii. p. 53. pl. 5. f. 10.

Ceylon; Singapore; Borneo, Sarawak; Bali ; Buru; Celebes; Gilolo; Batchian; Dutch N. Guinea; Louisiade Is., St. Aignan I. ; Queensland.

(9) † Tirathaba maculifera n. sp.

๙. Head and thorax white mixed with ferruginous; abdomen orangeyellow, the anal tuft white at tip. Forewing white, the costal area and submedian fold tinged with ferruginous; the wing mottled with ferruginous spots especially along submedian fold and an ill-defined subterminal band; a short 
streak in base of cell and spots at middle of cell and upper angle; a terminal series of points. Hindwing and underside orange-yellow.

․ Forewing entirely suffused with ferruginous, the veins streaked with ferruginous, the subterminal band just traceable, the spots absent.

Dutch N. Guinea, Ron J. (Doherty), 1 ô ; D'Entrecasteaux Is., Goodenough I. (Meek), 1 ô, Woodlark I. (Meek), 1 ô type, $q$ in coll. Rothschild ; Louisiade Is., St. Aignan I. (Meek), 1 ơ. Exp. 24-30 mill.

(10) † Tirathaba fuscistriata n. sp.

․ Head and thorax ochreous grey tinged with purplish red-brown; abdomen dull ochreous. Forewing ochreous grey tinged with purplish red-brown, the veins of costal half streaked with blackish; traces of postmedial and subterminal series of slight brownish spots; the apical part of costa and termen with series of dark striae; cilia pale purplish red, the tips dark towards apex, Hindwing dull ochreous, the costal area tinged with brown, the cilia pale purplish red. Underside dull ochreous; forewing with the disk suffused with fusccus, the costal and terminal areas tinged with purple; hindwing with the costal area suffused with fuscous.

Dutch N. Guinea, Dorey (Doherty), 1 ㅇ type. Exp. 30 mill.

\section{(11) * Tirathaba purpurella n. sp.}

ค. Head and thorax pale ochreous tinged with purplish; palpi fuscous at tips; metathorax edged with fuscous; abdomen ochreous, the anal tuft and ventral surface tinged with purple. Forewing purple suffused with fuscous, the veins streaked with fuscous; a rufous discoidal spot. Hindwing greyish fuscous, somewhat ochreous towards base; cilia purple on apical half.

Louisiade Is., St. Aignan I. (Meek), type + in coll. Rothschild. Exp. 38 mill.

\section{(12) Tirathaba grandinotella.}

† Tirathaba grandinotella Hmpsn., J. Bomb. N. H. Soc. xii. p. 96 (1898); id., Rom. Mém. viii. p. 462. pl. 45. f. 17.

Assam, Khásis ; Amboina.

(13) Tirathaba semifoedalis.

Botys semifoedalis Wlk., xxxiv. 1439 (1865); Hmpsn., Rom. Mém. viii. p. 462. pl. 54. f. 4.

Bhután; Celebes, Sula I.

\section{(14) Tirathaba parasitica.}

Melissoblaptes parasiticus Lueas, Pr. R. Soc. Queensl. xiii. p. 85 (1898).

Harpagoneura hepialivora Hmpsn., Rom. Mém. viii. p. 464. pl. 53. f. 19 (1901).

Queensland.

(15) Tirathaba haematella.

† Tirathaba haematella Hmpsn., Rom. Mém. viii. p. 463. pl. 54. f. 21 (1901).

Aru Is. 
$b^{1}$. Forewing of male without secondary sexual characters.

(16) Tirathaba unicolorella.

$\dagger$ Mucialla unicolorella Hmpsn., Moths Ind. iv. p. 5 (1896) ; id., Rom. Mém. viii. p. 463. pl. 54. f. 6.

Bhután; Assam, Khásis.

(17) † Tirathaba nitidalis n. sp.

\%. Head, thorax and abdomen white, the anal tuft brownish. Forewing silvery white, the costal edge black towards base; a diffused purplish-fuscous subterminal line, slightly excurved at middle, the area beyond it faintly tinged with purplish fuscous. Hindwing silvery white, the inner area slightly tinged with brown.

Dutch N. Guinea, Kapaur (Doherty), 1 type. Exp. 18 mill.

\section{Gen. Antiptilotis.}

Antiptilotis Meyr., Trans. Ent. Soc. 1897. p. 80

Type.

rubicunda

Proboscis fully developed; palpi of male short, upturned ; maxillary palpi slight; frons with large tuft of hair; antennae short, the basal joint with tuft of hair. Forewing narrow, the costa arehed at base, the a pex somewhat produced, the termen obliquely curved; cell long; vein 2 from middle of cell ; 3 from near angle; 4, 5 from angle; 6 from upper angle; 7, 8, 9, 10 stalked, 7 from beyond 9 ; 11 from cell ; the male with large glandular swelling at base of costa on underside fringed with hair at extremity met by a fringe of upturned hair from middle of median nervure. Hindwing with the apex produced and acute; the cell short, vein 2 from near angle of cell ; 3 and 5 stalked, 4 absent; the discocellulars angled; 6,7 shortly stalked, 7 not anastomosing with 8 ; the male with tuft of scales on upperside below base of cell.

\section{Antiptilotis rubicunda.}

$\dagger$ Antiptilotis rubicunda Meyr., Trans. Ent. Soc. 1897. p. 80 ; Hmpsn., Rom. Mém. viii. p. 467. pl. 54. f. 2 .

Melissoblaptes eucheliellus Snell., Tijd. v. Ent. xliii. p. 308. pl. 17. f. 9 (1900).

Java ; Celebes, Sangir I.

Gen. Corcyra.

Corcyra Rag., Ent. Mo. Mag. xxii. p. 23 (1885).

Proboscis almost obsolete; palpi of male short, upturned, thickly scaled, of female downcurved and extending about twice the length of head ; maxillary palpi minute; frons with large tuft of hair above; antennae short, the basal joint large and with tuft of hair below. Forewing narrow, the costa arched towards apex which is rounded, the termen obliquely curved; vein 2 from well beyond middle of cell ; 3 and 5 from angle, 4 absent; the discocellulars angled ; vein 6 from just below upper angle; $7,8,9$ stalked, 7 from beyond $9 ; 10,11$ from cell ; the male with slight glandular swelling at base of costa. Hindwing with vein 2 from near angle of cell ; 3 and 5 stalked, 4 absent ; the discocellulars retracted to near base; veins 6,7 from upper angle, 7 anastomosing with 8 . 


\section{(1) Corcyra cephalonica.}

Melissoblaptes cephalonica Sttn., Ent. Mo. Mag. ii. p. 172 (1865); Rag.. Rom. Mém. viii. p. 491. pl. 45. f. 23 ; Staud., Cat. Lep. pal. ii. p. 1.

Melissoblaptes oeconomellus Mann, Verh, zool.-bot. ges. Wien, 1872. p. 35.

\section{W. Indies; Brazil; Britain; Germany; Sicily ; Corcyra ; Bulgaria ; Seychelles; Asia Minor, Bithynia; Madras; Ceylon; Java ; Christmas I. ; Cocos Keeling I. ; N. Australia.}

(2) Corcyra translineella.

Corcyra translineella Rag., Rom. Mém. viii. p. 492. pl. 51. f. 26 (1901).

Sudan; Br. C. Africa; Réunion; Ceylon; Kei Is. Probably not distinct from C. cephalonica.

\section{(3) * Corcyra asthenistis.}

Corcyra asthenistis Turner, Pr. R. Soc. Queensl. xviii. p. 155 (1904).

Queensland.

\section{Gen. Arenipses.} Arenipses Hmpsn., Rom. Mém. viii. p. 501 (1901) . . . . . . . . sabella

Proboscis fully developed; palpi of male short, upturned and fringed with hair, of female downeurved and extending about three times length of head; frons with large tuft of hair; antennae short, the basal joint rather large. Forewing narrow, the apex rounded, the termen evenly curved; the cell in male very long and produced to a point at vein 5 ; veins $2,3,4,5$ given off at equal distances and parallel; the discocellulars very oblique; veins $6,7,8,9$ stalked, 7 from beyond $9 ; 10,11$ from cell ; the cell on underside clothed with fine silky hair and with a large glandular swelling filled with floceulent hair at base of costa ; of female with the cell normal; vein 3 from before angle of cell ; 4, 5 separate, the discocellulars angled. Hindwing with the cell open, the lower discocellular very faint and the upper absent; veins 3 and 5 stalked, 4 absent; 6,7 stalked, 7 anastomosing with 8 .

\section{Arenipses sabella.}

† Arenipses sabella Hmpsn., Rom. Mém. viii. p. 501. pl. 24. f. 1 (1901); Staud., Cat. Lep. pal. ii. p. 1.

\section{Algeria; Arabia; Persia.}

\section{Gen. Trachylepidia.}

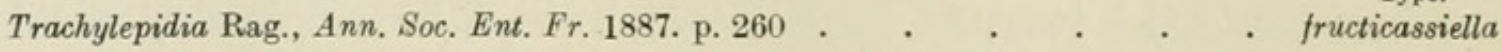

Proboscis slight; palpi of male short, upturned, thickly scaled, of female downcurved and extending about the length of head; maxillary palpi slight; frons with large tuft of hair; antennae of moderate length, the basal joint with tuft of scales below. Forewing narrow, the apex rounded, the termen evenly curved; the cell rather short; vein 2 from middle of cell ; 3 from well before angle ; 4, 5 from angle ; 6 from just below upper angle ; 7, 8, 9, 10 stalked, 7 from beyond $9 ; 11$ from cell ; the male with large glandular swelling at base of costa on underside, fringed with hair at extremity met by a fringe of upturned hair from middle of median nervure. Hindwing with vein 2 from near angle 
of cell ; 3 and 5 stalked, 4 absent ; the discocellulars angled to near base ; 6,7 from upper angle; 7 anastomosing with 8 .

\section{Trachylepidia fructicassiella.}

Trachylepidia fructicassiella, Rag. Ann. Soc. Ent. Fr. 1887. p. 260 ; id., Rom. Mém. viii. p. 469. pl. 46 , f. 15 .

Egypt; Mozambique; Transvaal; Syria; Punjab; Bengal ; Ceylon.

\section{Gen. Paraphomia.}

Paraphomia Hmpsn., Rom. Mém. viii. p. 501 (1901) .

Type.

vineteella

Proboscis slight; palpi of male short, upturned, of female downcurved and extending about the length of head; maxillary palpi slight; frons with small tuft of scales; antennae short, the basal joint long and dilated. Forewing with the costa arched, the apex rounded; the cell narrow and long; vein 2 from about the middle of cell ; 3 from well before angle ; 4,5 from angle; the discocellulars angled ; $6,7,8,9$ stalked ; 10,11 from cell ; the male with glandular swelling at base of costa on underside. Hindwing with vein 2 from near angle of cell; 3 and 5 strongly stalked, 4 absent; the discocellulars angled inwards almost to base ; 6,7 stalked, 7 anastomosing with 8 .

(1) * Paraphomia vineteella.

Paraphomia vineteella Hmpsn., Rom. Mém. viii. p. 502. pl. 55. f. 1 (1901).

Tenimber Is.; Queensland, Cedar Bay.

(2) * Paraphomia natalensis.

Paraphomia natalensis Hmpsn., Rom. Mem. viii. p. 502. pl. 55. f. 5 (1901).

Natal.

Gen. Aphomia.

Tinea Linn., Syst. Nat. edit. x. p. 496 (1858). partim $\ddagger$. . . . . . . ? sociella A phomia Hübn., Verz. p. 369 (1827) . . . . . . . . . . . . . . sociella § Melia Curt., Brit. Ent. vi. p. 201 (1829) nec Bilb. Crust. $1820 \quad$. . . . . sociella Meliana Curt., Brit. Ent. vi. Index (1829) . . . . . . . . . sociella Melissoblaptes Zell., Isis. 1839. p. 180 . . . . . . . . . . . . . foedella Bapara Wlk., xxxii. p. 620 (1865) . . . . . . . . . . . . . . . obliterosa Paralipsa Butl., A. M. N. H. (5). iv. p. 454 (1879) . . . . . . . . gularis

Proboscis fully developed; palpi of male short, upturned, thickly scaled, of female downcurved and extending about three times length of head ; maxillary palpi dilated with scales; frons with large tuft of hair above; antennae about half the length of wing, the 1st joint with tuft of scales below. Forewing rather narrow, the costa arched, the termen evenly curved; the males typically with the cell very large and extending almost to the termen; veins $3,4,5$ widely separated and parallel; the discocellulars almost obsolete, 6 from below upper angle of cell ; 7,8, 9 stalked, 7 from beyond $9 ; 10,11$ from cell ; a small glandular swelling at base of costa on underside and the whole cell clothed with fine silky scales; female with the cell about two-thirds length of wing; vein 3 from well before angle; 4, 5 from angle; the discocellulars strongly angled; 6 from

$\ddagger$ Cf. p. 17 .

$\S$ Curtis fixes the type as sociella, and his description and structural details on the plate of Senta flammea are from sociella. 
upper angle. Hindwing with the termen excised below apex; vein 2 from close to angle of cell; 3 and 5 strongly stalked, 4 absent; the discocellulars obsolescent and angled inwards to near base ; 6, 7 from upper angle, 7 anastomosing with 8 .

Sect. I. (Aphomia). Forewing of male with the cell very broad and extending almost to termen, veins $3,4,5$ widely separated and parallel, the discocellulars very indistinct, vein 6 from below upper angle; a small glandular swelling at base of costa on underside and the whole cell clothed with silky scales.

\section{(1) Aphomia sociella.}

Tinea sociella Linn., Syst. Nat. edit. x. p. 534 (1758) ô ; Rag., Rom. Mém. viii. p. 471 ; Staud., Cat. Lep. pal. ii. p. 1 ; Dyar, Cat. Lep. N. Am. p. 413.

Tinea colonella Linn., Syst. Nat. edit. x. p. 534 (1758) 우 ; Clerck, Icones. pl. 3. ff. 8. 11 ; Hübn.,

Eur. Schmidt. Tin. ff. 22, 23 ; Dup., Lép. Fr. x. pl. 282. f. 6 ; Steph., Ill. Brit. Ent. Haust. p. 296.

Tinea tribunella Schiff., Wien Vers. p. 319 (1776).

Aphomia sociella ab. rufinella Krul., Rev. Russ. Ent. viii. p. 274 (1909).

\section{N. America; Europe; Asia Minor; Syria.}

Sect. II. (Paralipsa). Forewing of male with the cell shorter and narrower, produced at extremity but not reaching to near termen, veins 3,4 , 5 well separated and parallel, 6 from below upper angle, a large glandular swelling at base of costa on underside extending to near middle of wing and fringed with long hair outwardly, the whole cell clothed with silky andrcconia.

\section{(2) Aphomia gularis.}

Melissoblaptes gularis Zell., Hor. Soc. Ent. Rosc. xiii. p. 74. pl. 1. f. 26 and pl. 2. f. 27 (1877).

† Paralipsa modesta Butl., A. M. N. H. (5). iv. p. 455 (1879) ơ ; Rag., Rom. Mém. viii. p. 474. pl. 43. f. 25.

† Melissoblaptes tenebrosus Butl., Ill. Het. B. M. iii. p. 78. pl. 60. f. 1 (1879) q.

Japan ; C. and W. China; Sikkim ; Bhután; Madras.

(3) * Aphomia spoliatrix.

Aphomia spoliatrix Christ., Bull. Nat. Mosc. lvi. p. 59 (1881); Rag., Rom. Mém. viii. p. 476. pl. 46. f. 14; Staud., Cat. Lep. pal. ii. p. 1.

E. Siberia.

(4) * Aphomia decolorella.

Paralipsa decolorella Hmpsn., Rom. Mém. viii. p. 474. pl. 55. f. 3 (1901).

D'Entrecasteaux Is., Fergusson I.

(5) † Aphomia ochracea n. sp.

๙. Pale ochreous slightly tinged with brown. Forewing irrorated with a few black scales, the costal and terminal areas slightly tinged with red; faint dark points at middle and end of cell ; traces of a curved postmedial line ; a terminal series of black points. Hindwing ochreous white.

․ Head, thorax and forewing whitish tinged and irrorated with purplish red; abdomen and hindwing suffused with brown.

Dutch N. Guinea, Jobi I. (Doherty) ; Louisiades Is., Woodlark I., St. Aignan (Meek), 1 ơ, 1 ㅇ type. Exp. के 24, ㅇ 26 mill. 
(6) * Aphomia erubella.

Paralipsa erubella Hmpsn., Rom. Mém. viii. p. 475. pl. 53. f. 20 (1901).

D'Entrecasteaux Is., Fergusson I.

(7) Aphomia terrenella.

Aphomia terrenella Zell., Isis, 1848. p. 859 ; Rag., Rom. Mém. viii. p. 476. pl. 56. f. 12.

† Melissoblaptes furellus Zell., Verk.zool.-bot.ges. Wien, 1873. p. 212; Dyar, Cat. Lep. N. Am. p. 413.

U.s.A., New York, Georgia.

(8) * Aphomia fulminalis.

Melissoblaptes fulminalis Zell., Verk. zool.-bot. ges. Wien, 1872, p. 560. pl. 3. f. 9 ; Dyar, Cat. Lep. N. Am. p. 413.

U.s.A., Texas.

(9) Aphomia stenopepla.

Paralipsa stenopepla Turner, Pr. R. Soc. Queensl. xviii. p. 156 (1904).

Queensland.

(10) Aphomia monochroa.

† Melissoblaptes monochroa Hmpsn., J. Bomb. Nat. Hist. Soc. xxi. p. 1249. pl. G. f. 29 (1912).

Ceylon.

(11) Aphomia vinotincta.

† Melissoblaptes vinotincta Hmpsn., J. Bomb. Nat. Hist. Soc. xviii. p. 257. pl. E. f. 38 (1908).

Ceylon.

(12) Aphomia rosella.

† Tirathaba rosella Hmpsn., J. Bomb. Nat. Hist. Soc. xii. p. 97 (1898); id., Rom. Mém. viii. p. 465. pl. 54. f. 8 .

\section{Assam.}

(13) $†$ Aphomia albifusa n. sp.

o. Head and thorax white mixed with pale brown; abdomen yellow brown. Forewing pale brown with broad fascia of white suffusion below costa extending at base to inner margin. Hindwing orange-yellow.

. Forewing entirely suffused with pale brown and irrorated with darker brown ; reddish streaks from base of median nervure in and below the cell; a dark terminal line.

Celebes, Sangir I. (Doherty), 1 ô, 1 ㅇ type. Exp. ô 26, 오 $30 \mathrm{mill}$.

Sect. III. (Melissoblaptes). Forewing of male with the cell extending to about two-thirds of wing, not produced at extremity, vein 3 from close to angle of cell ; 4, 5 shortly stalked; a large glandular swelling at base of costa on underside fringed with long hair outwardly met by some upturned hair from median nervure, the cell not clothed with androconia.

\section{(14) Aphomia bipunctana.}

Tinea anella Zinck., Germ. Mag. iv. p. 244 (nec Schiff.) ; Leech, Pyr. pl. 13. f. 4.

Melissoblaptes bipunctanus Zell., Isis, 1848. p. 580 (nec Curt.) ; Rag., Rom. Mém. viii. p. 480 ; Staud., Cat. Lep. pal. ii. p. 1.

Melissoblaptes bipunctanus var. sapozhnikovi Krul., Rev. Russ. Ent. viii. p. 274 (1909).

Europe ; E. Turkestan, Küldja ; Japan; N. China ; Ceylon. 
(15) Aphomia unicolor.

Melissoblaptes unicolor Staud., Hor. Ent. Soc. Ross. vii. p. 212 (1870); Rag., Rom. Mém. viii. p. 482. pl. 45. f. 21 ; Staud., Cat. Lep. pal. ii. p. 1.

Algeria; Greece; Bulgaria; Asia Minor, Bithynia.

\section{(16) * Aphomia foedella.}

Melissoblaptes foedella Zell., Isis, 1839. p. 180 ; Herr. Schäff., Eur. Schm. Pyr. ff. 147, 148 and iv. p. 133 ; Rag., Rom. Mém. viii. p. 483 ; Staud., Cat. Lep. pal. ii. p. 1.

Hungary ; Bohemia.

(17) * Aphomia isodesma.

Melissoblaptes isodesma Meyr., Trans. Ent. Soc. 1886. p. 272; Rag., Rom. Mém. viii. p. 484. pl. 5l. f. 14.

Fiji.

(18) Aphomia sordidella.

Gyrtona sordidella Wlk., xxxv. 1723 (1866); Rag., Rom. Mém. viii. p. 484. pl. 44. f. 25.

W. Australia; N. s. Wales.

(19) † Aphomia melanomochla n. sp.

․ Head, thorax and abdomen grey-white mixed with brown; antennae ringed fuscous and white. Forewing grey-white suffused in parts and irrorated with brown; a fine black streak in submedian fold to the postmedial line; a dark mark on median nervure before the antemedial line which is rather diffused, black-brown, oblique to submedian fold, and slightly incurved at vein 1; a black bar in cell towards extremity, and a rather lunulate discoidal bar defined on outer side by white; postmedial line rather diffused black-brown, defined on outer side by white to submedian fold where there is a dark mark beyond it, oblique and slightly sinuous to beyond lower angle of cell where it is acutely angled outwards, then inwardly oblique to submedian fold and erect to inner margin, some dark brown suffusion beyond it on costal area. Hindwing white, the terminal area slightly tinged with red-brown; a reddish brown terminal line and slight line near base of cilia.

w. Australia, Sherlock R. (Clements), 1 q type. Exp. 28 mill.

\section{(20) Aphomia phloeomima.}

Hypolophota phloeomima Turner, Ann. Queensl. Mus. x. p. 108 (1911).

N. Australia.

(21) * Aphomia aegidia.

Melissoblaptes aegidia Meyr., Trans. Ent. Soc. 1887. p. 252 ; Rag., Rom. Mém. viii. p. 485. pl. 51. f. 7.

\section{s. Australia.}

(22) * Aphomia disema.

Melissoblaptes disema Lower, Tr. R. Soc. S. Austr. xxix. p. 103 (1905).

victoria.

(23) Aphomia odontella.

† Melissoblaptes odontella Hmpsn., J. Bomb. Nat. Hist. Soc. xii. p. 96 (1901); id., Rom. Mém. viii. p. 485. pl. 54. f. 18.

Ceylon. 
(24) * Aphomia fuscolimbella.

Melissoblaptes fuscolimbella Rag., Nouv. Gen. p. 20 (1887) ; id., Rom. Mém. viii. p. 485. pl. 46. f. 11 ; Dyar, Cat. Lep. N. Am. p. 413.

U.S.A.

(25) Aphomia variegatella.

$\dagger$ Meliss blaptes variegatella Hmpsn., Rom. Mém. viii. p. 486. pl. 54. f. 19 (1901).

Borneo.

(26) Aphomia obliterosa.

Bapara obliterosa Wlk., xxxii. 603 (1865) ; Swinh., Cat. Het. Mus. Oxon. ii. pl. vii. f. 2 ; Hmpsn., Rom. Mém. viii. p. 487. pl. 53. f. 14.

N. Guinea; D'Entrecasteaux Is.

(27) * Aphomia distictella n. sp.

๙. Head and thorax brown irrorated with fuscous; abdomen fuscous. Forewing brown irrorated with fuscous ; a black point in end of cell and another on discocellulars. Hindwing dark fuscous-brown; the cilia paler with a dark line through them.

Natal (A. J. Spiller), type in coll. Rothschild. Exp. 22 mill.

(28) * Aphomia homochroa.

Melissoblaptes homochroa Turner, Pr. R. Soc. Queensl. xix. p. 53 (1905).

Queensland.

Sect. IV. Forewing of male with the cell extending to about two-thirds of wing; not produced at extremity; veins 3, 4 from angle of cell ; 5 from above angle; a small glandular swelling at base of costa on underside, the cell clothed with silky androconia; hindwing with tuft of long hair from below costa near base on upperside.

(29) † Aphomia cyclophora n. sp.

๙. Head, thorax and abdomen whitish tinged with pale purplish red. Forewing pale purplish red irrorated with blackish; a minute annulus incompletely defined by black scales in middle of cell and a more complete discoidal annulus; traces of a diffused dark postmedial line, oblique to vein 5 , then inwardly oblique and somewhat dentate; traces of a curved dark subterminal line; a terminal series of black bars. Hindwing ochreous yellow tinged with brown except on inner area; a slight brown terminal line; cilia brownish to vein 2 with a pale line at base, then yellowish. Underside ochreous white tinged with brown, forewing with the cell clothed with golden yellow androconia; hindwing with the tuft of hair ochreous.

Br. N. Guinea, Milne Bay (Meek), 1 ô type. Exp. 34 mill.

Sect. V. Forewing of male with the cell extending to ahout two-thirds of wing, not produced at extremity ; vein 3 from before angle of cell ; 4, 5 from angle; the wings without secondary sexual characters. 
(30) † Aphomia caffralis $\mathrm{n}$. sp.

o. Head and thorax grey tinged with purplish red and with some blackish mixed; abdomen pale grey with a faint ochreous tinge towards base and some fuscous brown suffusion towards extremity; pectus, legs and ventral surface of abdomen whitish irrorated with blackish, the tarsi banded with blackish. Forewing grey tinged with purplish red and sparsely irrorated with black; a diffused whitish streak in submedian fold from before the antemedial to the postmedial line; a black point at base of vein 1, and subbasal point in the cell ; antemedial line rather diffused, blackish, oblique to submedian fold, then erect; rather diffused black spots in cell towards extremity and on discocellulars, with a few white scales between them; postmedial line rather diffused blackish, defined on outer side by some white scales, rather obliquely incurved to discal fold, then inwardly oblique; a punctiform blackish terminal line ; cilia with a slight pale line near tips. Hindwing whitish suffused with reddish brown, the cilia whiter with two dark lines through them except towards tornus. Underside of forewing fuscous with the costal edge pale; hindwing whitish tinged with red-brown, the costal area suffused with fuscous.

Transvaal, Kranspruit (Jause), 1 ot type; Orange R. Colony, Bloemfontein (Eckersley), 1 o. Exp. 26-30 mill.

\section{Auctorum.}

A phonia erumpens Lucas, Pr. R. Soc. Queensl. xiii. p. 79 (1898) . . . . . . Queensland Melissoblaptes burellus Holl., Nov. Zool. vii. p. 581 (1900) . . . . . . . . . Buru Melissoblaptes baryptera Lower, P. Linn. Soc. N.S.W. 1901. p. 659 . Victoria ; S. Australia Melissoblaptes agramma Lower, Tr. R. Soc. S. A ustr. 1903. p. 49 . Louisiades Is.; Queensland Melissoblaptes cissinobaphes Turner, Tr. R. Soc. Queensl. xix. p. 90 (1905) . . . . Queensland A phomia grisea Turati, Ent. Rec. xxv. p. $18(1913)$. . . . . . . . . Sardinia

\section{GEN. Heteromicta.}

Heteromicta Meyr., Trans Ent. Soc. 1886. p. 273 Hypolophota Turner, Pr. R. Soc. Queensl. xviii. p. $155(1903) \quad$. . . . . . . oodes

Proboscis fully developed; palpi of male upturned, short, thickly scaled, of female obliquely porrect and extending about the length of head; maxillary palpi minute, filiform ; frons with large tuft of hair ; antennae of male almost simple, the first joint rather long. Forewing rather short and broad, the costa moderately arched, the apex rounded; veins 3 and 5 from near angle of cell; 6 from upper angle; $7,8,9$ stalked from before angle, 7 from before $9 ; 10,11$ from cell ; the male typically without secondary sexual characters. Hindwing with vein 2 from near angle of cell ; 3 and 5 strongly stalked, 4 absent; the discocellulars angled inwards to near base ; 6,7 from upper angle ; 7 anastomosing with 8 .

Sect. I. (Hypolophota). Forewing of male on underside with costal fold extending to beyond middle of wing and containing large masses of flccculent hair, vein 5 well separated from 4.

\section{(1) Heteromicta amydrastis.}

Hypolophota amydrastis Turner, Pr. R. Soc. Queensl. xviii. p. 156 (1904).

Queensland. The forewing (fide Turner) sometimes has vein 7 from 8 beyond 9 . 
(2) Heteromicta oodes.

Hypolophota oodes Turner, Pr. R. Soc. Queensl. xviii. p. 155 (1904). absent.

Queensland. The two specimens in B.M. have vein 9 of the forewing

Sect. II. (Heteromicta). Forewing of male without secondary sexual characters, vein 5 from close to 4.

(3) Heteromicta pachytera.

A phomia pachytera Meyr., Proc. Linn. Soc. N.S.W. 1879. p. 237 ; Rag., Rom. Mém. viii. p. 453. pl. 45. fi. 19. 20.

Queensland; N. S. Wales; Victoria; S. Australia ; Tasmania.

(4) * Heteromicta poliostola.

Heteromicta poliostola Turner, Pr. R. Soc. Queensl. xviii. p. 158 (1903).

\section{Queensland.}

(5) Heteromicta tripartitella.

Aphomia tripartitella Meyr., Proc. Linn. Soc. N.S.W. 1879. p. 236 ; Rag., Rom. Mém. viii. p. 454. pl. 46. f. 9.

Queensland; N. S. Wales.

(6) Heteromicta ochraceella.

Heteromicta ochraceella Hmpsn., Rom. Mém. viii. p. 455. pl. 54. f. 1 (1901).

Queensland.

(7) * Heteromicta nigricostella.

Heteromicta nigricostella Hmpsn., Rom. Mém. viii. p. 455. pl. 54. f. 3 (1901).

Queensland.

Auctorum.

Heteromicta poeodes Turner, Pr. R. Soc. Queensl. xix. p. 54 (1905) . . . Q Queensland

Hypolophota agasta Turner, Ann. Queensl. Mus. x. p. 109 (1911)? A phomia Queensland; N. Australia

Heteromicta alypeta Turner, Ann. Queensl. Mus. x. p. 109 (1911) . . . Queensland

Heteromicta leptochlora Turner, Pr. R. Soc. Queensl. xxiv. p. 129 (1913) . . . Queensland

Type A. petrochroa.

\section{Gen. Agdistopis nov.}

Proboscis aborted, minute; palpi obliquely porrect, the second joint with some rough scales and extending about twice the length of head, the third moderate and somewhat dilated at extremity ; maxillary palpi absent ; frons with small tuft of hair; antennae of male somewhat laminate and with fasciculate cilia ; legs long, the fore tibiae slight, fringed with hair, the mid and hind tibiae smoothly scaled, the hind tibiae curved and with the medial spurs absent; abdomen very long and tipuliform. Forewing very long and narrow, the apex rounded, the termen evenly curved; the cell about two-thirds length of wing; vein 3 from close to angle; 4, 5 stalked; the discocellulars curved; 6 from upper angle ; 7, 8, 10 stalked, 9 absent ; 11 from cell, some rough hair from base of costa on underside. Hindwing with some rough hair from base of costa, but 
the retinaculum absent; the apex produced and acute, the termen very oblique and somewhat excised below apex; veins 3 and 5 from angle of cell, 4 absent; the discocellulars erect; 6 absent ; 7 from upper angle, closely approximated to but not anastomosing with 8 .

The genus has a remarkable superficial resemblance to Agdistis.

\section{Agdistopis petrochroa n. sp.}

Head, thorax and abdomen ochreous white with a brownish tinge, the last with paler segmental bands and slight dark sublateral streaks; legs rather browner. Forewing ochreous white with some blackish irroration especially below and beyond the cell, the costal area paler; a diffused oblique black fascia intersected by a pinkish streak below basal half of cell. Hindwing whitish tinged with fuscous brown, thinly scaled; cilia with a fine ochreous line at base.

$H a b$. Formosa, Kanshirei in coll. Wileman; Ceylon, Kandy (Mackwood), ơ type; Singapore (Ridley), 2 ô, 2 +. $\operatorname{Exp} .22-30$ mill.

\section{Genus Achroia.}

Achroia Hübn., Verz. p. 163 (1827) not preoce. by Acraea Hübn., Verz. p. 92 • $\quad$ grisella Meliphora Guen, Ann. Soc. Ent. Fr. xiv. p. 308 (1845), not descr. . . . . . grisella Vobrix Wlk., xxx. 1014 (1864) . . . . . . . . . . . . . . . innotata

Proboscis slight; palpi of male minute, upturned, hidden under the downturned hair on frons; of female downturned and extending to beyond the frons; maxillary palpi minute and dilated with scales; antennae rather long, the basal joint rather long and with tuft of scales below. Forewing elliptical, the costa arched, the apex rounded, the termen obliquely curved; male with vein 3 from before angle of cell ; 4, 5 from angle ; the discocellulars very oblique ; 6 from upper angle ; 7,8 and 10 stalked, 7 from beyond 10,9 absent ; 11 from cell; female with the discocellulars less oblique, vein 3 from angle of cell and 4, 5 stalked. Hindwing of male with the apex produced and acute, the termen excised to vein 1 and obliquely truncate at tornus; vein 2 from well before angle of cell; 3 and 5 stalked, 4 absent; the discocellulars angled; 6,7 from upper angle of cell, 7 anastomosing with 8 ; female with the apex less produced and the termen less excised, the cell shorter, vein 2 from near angle and 3 and 5 more strongly stalked.

\section{(1) * Achroia obscurevittella.}

Achroia obscurevittella Rag., Rom. Mém. viii. p. 498. pl. 43. f. 24 (1901).

Japan. Probably not distinct from A. grisella.

(2) Achroia grisella.

Tinea grisella Fabr., Ent. Syst. iii. 2. p. 289 (1794); Hmpsn., Moths Ind. iv. p. 6; Rag., Rom. Mém. viii. p. 497 ; Staud., Cat. Lep. pal. ii. p. 1.

Galleria alvearia Fabr., Ent. Syst. Suppl. p. 463 (1798).

Bombyx cinereola Hübn., Eur. Schm. Bomb. f. 91 (1802).

U.S.A. ; Jamaica ; Europe ; Sikkim ; Bengal, Calcutta ; Ceylon ; Australia.

(3) Achroia innotata.

† Vobrix innotata Wlk., xxx. 1014 (1864); Rag., Rom. Mém. viii. p. 498. pl. 55. f. 8.

Ceylon; Borneo, Sarawak. Probably not distinct from A. grisella. 
Auctorum.

Meliphora myrmecophila Turner, Pr. R. Soc. Queensl. xxiv. p. 130 (1913) .

Queensland

\section{Gen. Athaliptis.}

Athaliptis Schaus, A. M. N. H. (8). xi. p. 252 (1913) .

Type.

cymonia

Palpi of female long, downcurved, slender; antennae almost simple. Forewing long and narrow, the apex rounded, the termen evenly curved; vein 3 from before angle of cell ; 4, 5 from angle; 6 from just beiow upper angle; $7,8,9,10$ stalked, 7 from before 9 and beyond $10 ; 11$ from cell. Hindwing with veins 3 and 5 stalked, 4 absent; the discocellulars angled inwards to near base; 6,7 stalked.

\section{* Athaliptis cymonia.}

Athaliptis cymonia Schaus, A. M. N. H. (8). xi. p. 252 (1913).

\section{Costa Rica:}

\section{Gen. Epimorius.}

Epimorius Zell., Hor. Soc. Ent. Ross. xiii. p. 76 (1877). . . . . . . . suffusa

Proboscis slight; palpi of male short, upturned, thickly scaled, of female downcurved and extending typically about twice the length of head; maxillary palpi minute; frons with tuft of hair; antennae of male typically serrate. Forewing with the costa arched, the apex rounded, the termen obliquely curved; vein 3 from close to angle of cell ; 4,5 typically shortly stalked; the discocellulars strongly angled inwards ; 6 from just below upper angle ; 7, 8, 9, 10 stalked, 9 from beyond $7 ; 11$ from cell. Hindwing typically with vein 2 from close to angle of cell ; $3,4,5$ stalked; the discocellulars angled inwards to near base; 6,7 stalked, 7 anastomosing with 8 .

Sect. I. Palpi of female extending about three times length of head; antennae of male serrate ; forewing with veins 4,5 shortly stalked, the discocellulars strongly angled inwards; hindwing with veins $3,4,5$ stalked and the discocellulars angled inwards to near base.

\section{(1) Epimorius suffusa.}

Epimorius suffusus Zell., Hor. Ent. Soc. Ross, xiii. p. 76. pl. ii. f. 28 (1877); Rag., Rom. Mém. viii. p. 430. pl. 46. f. 3 .

Costa Rica; S. Brazil.

\section{(2) * Epimorius testaceella.}

Epimorius testaceellus Rag., N. Am. Phyc. p. 20 (1887); id., Rom. Mém. viii. p. 430. pl. 45. f. 22.

Jamaica.

(3) † Epimorius epipaschiella n. sp.

o. Head and thorax pale rufous tinged with grey and irrorated with blackish, the palpi with more black; abdomen white faintly tinged with brown ; tarsi blackish with pale rings. Forewing grey tinged with rufous and irrorated with blackish; the basal area suffused and irrorated with black to just before 
the medial line, which is black, inwardly oblique and incurved from subcostal nervure to just below the cell; the costal area beyond it whitish; a small rather oblique black discoidal spot; postmedial line black, diffused on inner side and defined on outer side by whitish, inwardly oblique, and with its outer edge minutely dentate, a blackish shade beyond it; the terminal area greywhite with some black at costa and a terminal series of minute black spots. Hindwing white, faintly tinged with brown ; a slight dark terminal line. Underside of forewing white tinged with fuscous ; hindwing with the costa slightly irrorated with fuscous.

Colombia, Minca (H. H. Smith), 1 o type. Exp. 16 mill.

Sect. II. Palpi of female extending about twice the length of head; antennae of male ciliated; forewing with veins 4,5 strongly stalked, the discocellulars less strongly angled inwards; hindwing with vein 3 from near angle of cell and the discocellulars not so strongly angled inwards.

\section{(4) † Epimorius adustalis n. sp.}

Head, thorax, and abdomen grey-brown with a slight reddish tinge. Forewing grey-brown with a slight reddish tinge and some black irroration; a slight discoidal spot formed by black scales ; traces of an obliquely curved postmedial black line; a terminal series of black points. Hindwing and underside greybrown with a slight reddish tinge.

Sierra Leone (Clements), 4 ô, 1 \% type ; $\mathbf{s . ~ N i g e r i a , ~ L a g o s ~ ( S i r ~ G . ~ C a r t e r ) , ~} 1$, Old Calabar (Crompton), 1 ; ; Sapele (Sampson), 1 ; ; Warri (Roth.), 1 ․ Exp. o $18-22$, 우 26-30 mill.

\section{Gen. Cathayia.}

Cathayia Hmpsn., Rom. Mém. viii. p. 451 (1901) . . . . . . . . obliquella

Proboscis slight; palpi of male short, upturned, thickly scaled, of female downcurved and extending about the length of head; maxillary palpi minute : frons with large tuft of hair; antennae of male rather short, the basal joint somewhat dilated. Forewing triangular, the costa arched, the apex somewhat produced and rounded, the termen oblique; the cell about twc-thirds length of wing; vein 3 from well before angle ; 4, 5 separate in male, in female stalked or from a point ; 6 from upper angle ; 7,8 stalked from 10, 9 absent or frem beyond 7 , arising before the angle of cell ; 11 from cell ; the male on underside with a small glandular swelling at base of costa with a large tuft of black hair from below its extremity, the base of median nervure and cell clothed with rough androconia. Hindwing with vein 3 from angle of cell; 4, 5 stalked; the discocellulars angled inwards to near base; veins 6,7 stalked, 7 anastomosing with 8 .

\section{(1) Cathayia obliquella.}

Cathayia obliquella, Hmpsn. Rom. Mém. viii. p. 452. pl. 51. f. 6 (1901).

Japan ; C. China.

(2) Cathayia purpureotincta n. sp.

․ Head and thorax rufous with a few blackish scales; abdomen paler rufous; palpi with a slight purplish tinge; pectus, legs and ventral surface of 
abdomen rufous, the last with some blackish irroration. Forewing bright rufous irrorated with black and slightly tinged with purple, the veins with slight pale streaks; an obscure mark formed by an aggregation of black scales in upper angle of cell and an oblique bar formed by black scales at middle of submedian interspace; traces of an oblique postmedial line formed by black scales from vein 5 to inner margin; cilia with a fine pale line at base. Hindwing ochreous tinged and irrorated with brown, the eilia with a faint purplish line thrcugh them from apex to vein 2. Underside reddish ochreous irrorated with dark brown ; forewing tinged with purplish red, the disk sufiused with brown, a faint curved blackish postmedial line.

Hab. Borneo, Kuching, 1 f type. Exp. 32 mill.

\section{Gen. Picrogama.}

Picrogama Meyr., Trans. Ent. Soc. 1897. p. 91

Proboscis rather short; palpi of male short, upturned, thickly scaled; of female downcurved and extending about twice the length of head ; maxillary palpi slight; frons with large tuft of hair; antennae of male almost simple, the basal joint somewhat dilated. Forewing narrow, the apex rectangular, the termen evenly curved; the male with the lower part of cell produced, vein 3 from well before angle, 5 from above angle; the discocellulars angled inwards above and with a recurrent vein from their angle ; 6 from upper angle ; 7, 8, 9 stalked from before the angle, 7 ty pically from beyond $9 ; 10,11$ from cell ; a small glandular swelling at base of costa on underside and the cell elothed with androconia; the female with veins 4,5 from angle of cell, the discocellulars incurved. Hindwing with vein 3 from just before angle of cell ; 4, 5 strongly stalked, the discocellulars angled inwards to near base ; 6,7 from upper angle, 7 anastomosing with 8 .

Sect. I. Forewing with vein 7 from 8 beyond 9 .

\section{(1) Picrogama complana.}

A phomia complana Feld., Reis. Nov. pl. 137. f. 6 (1874).

Picrogama anticosma Meyr., Trans. Ent. Soc. 1897. p. 92 ; Hmpsn., Rom. Mém. viii. p. 445. pl. 53. ff. 10. 11 .

Celebes, Sangir I. ; Amboina ; Dutch N. Guinea; D'Entrecasteaux Is., Goodenough I., Fergusson I. ; Iouisiade Is., St. Aignan I.

Sect. II. Forewing with vein 7 from 8 before 9 .

(2) † Picrogama albifascialis n. sp.

o. Head and thorax whitish tinged with red-brown; abdomen deep golden yellow. Forewing whitish tinged with brown and irrorated with dark brown, a purplish red tinge in lower part of cell and below vein 6 to termen; the veins of costal area with chocolate-brown streaks and two slight purple-brown streaks in the cell; a white fascia from base through the upper part of cell to apex broken up by the dark streaks on the veins; small elongate elliptical purplebrown spots in upper part of cell ; an aggregate of dark scales at origin of vein 2 ; an obliquely curved postmedial shade formed by aggregations of dark scales 
in the interspaces from below the white fascia to above inner margin ; a terminal series of slight black lunules. Hindwing deep golden yellow; the eilia with a brown line at middle and white tips. Underside deep golden yellow, the terminal area of forewing and apex of hindwing greyish tinged with purple-red.

Br. N. Guinea, Milne Bay (Meek), 1 ơ type. Exp. 46 mill.

\section{(3) Picrogama nigrisparsalis.}

$\dagger$ Lamoria nigrisparsalis Hmpsn., J. Bomb. Nat. Hist. Soc. xiv. p. 658 (1903).

\section{Ceylon.}

\section{Gen. Prosthenia.}

Prosthenia Hmpsn., Rom. Mém. viii. p. 450 (1901)

Type.

psittacolella

Proboscis small; palpi of male short, upturned, thickly scaled, of female with the second joint obliquely upturned to about vertex of head and bent forward at extremity, the third porrect; maxillary palpi slight; frons with large tuft of hair ; antennae of male almost simple, the basal joint with tuft of scales below. Forewing very narrow, the apex rounded, the termen very short; the male with veins $2,3,4,5$ given off at even distances, the cell being strongly produced to a point at vein $5 ; 6$ from upper angle ; 7, 8, 9 stalked, 7 from beyond 9 ; 10,11 from cell ; a large costal fold on basal third of costa on underside with thick fringe of hair below and the cell clothed with androconia ; the female with vein 3 from well before angle of cell, veins 4, 5 from angle, the discocellulars angled. Hindwing with vein 3 shortly stalked with 4, 5; the discocellulars angled inwards to near base; 6,7 staiked, 7 anastomosing with 8 .

\section{(1) Prosthenia psittacolella.}

† Prosthenia psittacolella Hmpsn., Rom. Mém. viii. p. 450. pl. 54. f. 11 (1901). Hornigia sauberi Semp., Reis. Phil. Schmett. ii. p. 644. pl. 66. f. 1 (1902).

\section{Singapore; Borneo; Philippines.}

(2) † Prosthenia xyloryctella, n. sp.

․ Head, thorax and abdomen whitish tinged with brown; antennae brown ringed with white; tarsi dark brown ringed with white. Forewing whitish tinged with purplish brown and irrorated with dark brown ; antemedial line dark brown defined on inner side by whitish, oblique, sinuous ; two blackbrown points in the cell towards extremity ; an oblique purple-brown discoidal lunule defined except on outer side by deep chocolate-brown and with a small chocolate-brown spot at its lower extremity; postmedial line dark brown, curved, dentate, defined on outer side by whitish with a diffused dentate brown shade beyond it except on costal area; the costa towards apex with white points with short black streaks between them and the costal area whitish; a terminal series of black striae, forming a rather triangular spot below apex; cilia whitish with slight brown line near base and stronger line near tips. Hindwing whitish tinged with brown; a dark terminal line and faint line near base of cilia from apex to submedian fold. Underside whitish tinged with brown ; forewing with the markings less distinct; hindwing with curved brown postmedial line from costa to vein 2.

Queensland, Toowong (Dodd), 1 \& type. Exp. 40 mill. 
The specimen is labelled "found in xylo-stick, supposed to be parasitic on the pupae of Xyloryctidae." This and the other species of the genus are probably not parasitic but feed on the faeces and rubbish in the one case in the nest of the parrots, in the other in the borings of the Xyloryctidae.

\section{Gen. Acara.}

Acara Wlk., xxvii. 198 (1863)

Ertzica Wlk., xxxv. 1768 (1866)

Proboscis short; palpi of male short, upturned, fringed in front with long hair, of female obliquely downcurved, extending about twice the length of head and fringed below with long hair; maxillary palpi minute; frons with large tuft of hair ; antennae of male almost simple, the basal joint with a tuft of scales below. Forewing with the costa slightly arched, the apex produced and acute, the termen evenly curved; the male with the cell about two-thirds length of wing; veins 2, 3, 4, 5 given off at even distances; the discocellulars angled inwards above; vein 6 from upper angle; 7, 8, 9 stalked from angle, 7 from beyond $9 ; 10,11$ from cell ; a large glandular fold on basal half of costa on underside, fringed with hair at extremity; female with the cell shorter, vein 3 from near angle of cell, 5 from just above angle, the discocellulars angled inwards at middle. Hindwing with the apex produced and acute, the termen excised below apex ; vein 3 from just before angle of cell ; 4,5 shortly stalked ; the discocellulars angled inwards to near base ; 6,7 stalked, 7 not anastomosing with 8 .

\section{Acara morosella.}

† Acara morosella Wlk., xxvii. 199 (1863); Hmpsn., Moths Ind. iv. p. 8; Rag., Rom. Mém. viii. p. 446. pl. 46. f. 10.

† Ertzica maximella Wlk., xxxv. 1768 (1866).

Galleria macroptera Snell., Tijd. v. Ent. xxiii. p. 249 (1879); id., idem. xxvii. p. 53. pl. v. f. 11.

Acara impunctella Sauber, Semp. Reis. Phil. Schmett. ii. p. 645. pl. 66. f. 2 (1902).

\section{Assam ; Ceylon; Philippines; Java ; Celebes.}

\section{Auctorum.}

Acara psolopasta Turner, Pr. R. Soc. Queensl. xxiv. p. 131 (1913) ? Eucallionyma. Queensland

\section{GEN. Schistotheca.}

Schistotheca Rag., Bull. Soc. Type.

Proboscis slight; palpi of male short, upturned, thickly scaled, of female downcurved and extending about three times length of head; frons smooth, with large tuft of hair; antennae of male almost simple. Forewing with the costa arched, the apex rectangular, the termen evenly curved; the male with vein 3 from long before angle of cell ; 5 from just above angle ; the discocellulars highly angled inwards ; vein 6 from below upper angle; 7, 8, 9 stalked, 7 from before $9 ; 10,11$ from cell; a large fold on basal half of costa on underside containing masses of flocculent hair; the female with veins 4,5 from a point. Hindwing with vein 3 from close to angle of cell ; 4, 5 stalked; the discocellulars angled inwards to near base ; 6,7 from upper angle, 7 not anastomosing with 8 . 
(1) Schistotheca canescens.

$\dagger$ Schistotheca canescens Rag., Bull. Soc. Ent. Fr. (6). ii. p. clxxv. (1882); id., Rom. Mém. viii. p. 429. pl. 45. f. 15.

Chili.

(2) Schistotheca gigantella.

Crambus gigantella Druce, A. M. N. H. (8). viii. p. 720 (1911).

Peru.

GEN. Lamoria.

Lamoria Wlk., xxvii. $87(1863) \quad$. $\quad . \quad$. $\quad . \quad$. . . . . . . . adaptella

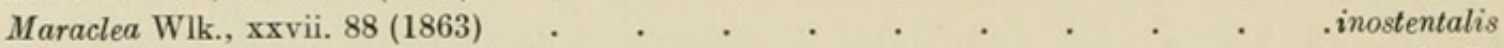

Tugela Rag., Nouv. Gen. p. 51 (1888) . . . . . . . . . . clathrella

Proboscis minute; palpi of male short, upturned, thickly scaled, of female porrect, extending about twice the length of head and fringed with hair below ; maxillary palpi minute; frons with large tuft of hair ; antennae of male almost simple, the basal joint rather dilated. Forewing narrow, the costa arched, the apex rounded ; vein 3 from close to angle of cell ; 4, 5 stalked, from a point, or separate; the discocellulars curved; 6 from just below upper angle, from angle, or shortly stalked with $7,8,9,7$ from before $9 ; 10,11$ from cell ; the male with glandular swelling at base of costa on underside. Hindwing with vein 2 from near angle of cell ; 3, 4, 5 stalked; the discocellulars angled inwards to near base; 6,7 stalked, 7 anastomosing with 8 .

Sect. I. Forewing with veins 4,5 separate.

A. Hindwing of male on upperside clothed with golden brown androconia except on terminal area and on underside along the median nervure and veins 4 to 2 .

\section{(1) Lamoria pachylepidella.}

Lamoria pachylepidella Hmpsn., Rom. Mém. viii. p. 441. pl. 53. f. 3 (1901).

\section{Queensland.}

B. (Maraclea). Hindwing of male normal.

(2) Lamoria oenachroa.

Lamoria oenachroa Turner, Pr. R. Soc. Queensl. xix. p. 55 (1905).

\section{Queensland; W. Australia.}

(3) Lamoria inostentalis.

† Maraclea inostentalis Wlk., xxvii. 88 (1863); Hmpsn., Rom. Mém. viii. p. 436. pl. 53. f. 2.

Japan ; Formosa ; C. and W. China ; Borneo; D'Entrecasteanx Is., Fergusson I. The hindwing often has vein 4 absent.

\section{(4) † Lamoria medianalis $\mathrm{n}$. sp.}

o. Head and thorax pale purplish grey mixed with blackish; abdomen ochreous white, tinged with rufous at base ; legs grey tinged with brown ; ventral surface of abdomen whitish irrorated with brown. Forewing pale purplish grey irrorated with blackish, with a dark shade along median nervure and whiter shades in the cell and submedian interspace; a small obscure discoidal spot tinged 
with rufous; a faint slightly dentate brown postmedial line, oblique to vein 4, then inwardly oblique; a terminal series of blackish points. Hindwing ochreous white, the terminal area tinged with brown except towards tornus. Underside of forewing grey-brown; hindwing whitish, the costal area tinged with brown.

Mashonaland (Dobbie), 1 ô type. Exp. 34 mill.

Sect. II. (Lamoria). Forewing with veins 4, 5 from a point or stalked.

(5) Lamoria anella.

Tinea anella Schiff., Wien Vers. p. 135 (1776) ; Dup., Lép. Fr. x. p. 261. pl. 282. f. 7 ; Herr. Schäff, Schmett. Eur. iv. p. 113. f. 151 ; Rag., Rom. Mém. viii. p. 438 ; Staud., Cat. Lep. pal. ii. p. 2. Tinea sociella Hübn., Eur. Schmett. Tin. f. 24 (nec Linn).

Melia bipunctana Curt., Brit. Ent. v. p. 201 (1830).

\section{S. Centr. and S. Europe; Egypt.}

(6) Lamoria melanophlebia.

Lamoria melanophlebia Rag., Nouv. Gen. p. 51 (1888); id., Rom. Mém. viii. p. 435. pl. 46. f. 6 ; Staud., Cat. Lep. pal. ii. p. 2.

Russia, Caucasus ; Syria.

(7) Lamoria ruficostella.

Lamoria ruficostella Rag., Nouv. Gen. p. 52 (1888); id., Rom. Mém. viii. p. 436. pl. 45. f. 11 ; Staud., Cat. Lep. pal. ii. p. 2.

\section{S. Russia ; Japan ; C. China.}

(8) * Lamoria caffrella.

Tugela caffrella Rag., Nouv. Gen. p. 51 (1888); id., Rom. Mém. viii. p. 442. pl. 46. f. 6.

Natal.

(9) Lamoria jordanis.

Lamoria jordanis Rag., Rom. Mém. viii. p. 435. pl. 46. f. 5 (1901) ; Staud., Cat. Lep. pal. ii. p. 2. Ceylon.

Tunis; Egypt; Cyprus; Syria; Palestine; Persian Gulf; Punjab; Sind;

(10) Lamoria imbella.

† Acrobasis imbella Wlk., xxx. 955 (1864); Rag., Rom. Mém. viii. p. 437. pl. 45. f. 12.

Melissoblaptes obscurellus Saalm., Ber. Senck. Ges. 1880. p. 308 ; id., Lep. Maday, p. 511.

N. Nigeria ; Br. E. Africa ; Br. C. Africa; Mrashonaland; Transvaal; Natal;

C. Colony ; Madagascar.

(11) Lamoria clathrella.

Tugela clathrella Rag., Nouv. Gen. p. 51 (1888); id., Rom. Mém. viii. p. 442. pl. 46. f, 1.

Madagascar.

(12) Lamoria adaptella.

Pempelia adaptella Wlk., xxvii. 74 (1853) ; Rag., Rom. Mém. viii. p. 434. pl. 35. f. 21.

Lamoria planalis Wlk., xxvii. 88 (1853).

Crambus foedellus Wlk., xxxv. 1757 (1866).

Lamoria fusconervella Rag., Nouv. Gen. p. 51 (1888) ; id., Rom. Mém. viii. p. 437. pl. 45. f. 13.

Melissoblaptes bipunctanus Moore, Lep. Ceyl. iii. p. 375 (nec Haw).

Lamoria anella Hmpsn., Moths Ind. iv. p. 7 (nec Schiff).

Formosa; Madras; Ceylon; Singapore ; Sumatra; Java ; Flores. 
(13) Lamoria infumatella.

† Lamoria infumatella Hmpsn., J. Bomb. Nat. Hist. Soc. xii. p. 98 (1898); id., Rom. Mém. viii. p. 440. pl. 53. f. 5 .

Sikhim ; Ceylon.

(14) Lamoria virescens.

† Lamoria virescens Hmpsn., J. Bomb. Nat. Hist. Soc. xii. p. 97 (1898); id., Rom. Mém. viii. p. 440. pl. 537. f. 1.

Sikhim ; Ceylon; Queensland.

GEN. Acyperas.

Acyperas Hmpsn., Rom. Mém. viii. p. 427 (1901)

Type.

aurantiacella

Proboscis minute; palpi in both sexes downcurved, extending about twice the length of head and moderately fringed with hair below ; maxillary palpi filiform ; frons with large tuft of hair; antennae of male short, almost simple, the basal joint dilated, hollowed out on outer side and with tuft of hair in front. Forewing with the costa arched to beyond middle, then oblique to apex which is produced and acute, the termen evenly curved; vein 3 from long before angle of cell ; 4, 5 separate in male, from a point in female; the discocellulars curved; vein 6 from upper angle; 7, 8, 9 stalked, 7 from beyond 9 ; 10,11 from cell; the male with large glandular swelling at base of costa on underside, fringed with oblique hair met by a tuft of hair from median nervure. Hindwing with the cell short ; vein 3 from close to angle of cell ; 4, 5 strongly stalked ; the discocellulars acutely angled; 6,7 stalked, 7 anastomosing slightly with 8 .

\section{Acyperas aurantiacella.}

Acyperas aurantiacella Hmpsn., Rom. Mém. viii. p. 427. pl. 53. f. 15 (1901).

\section{N. Guinea ; D'Entrecasteaux Is.}

\section{Gen. Omphalophora.}

Omphalophora Hmpsn., Rom. Mém. viii. p. 427 (1901)

Type.

Proboscis minute; palpi in both sexes downcurved, extending about the length of head and clothed with long hair below; maxillary palpi dilated with scales; frons with large tuft of hair; antennae short, almost simple, the basal joint dilated, hollowed out on outer side and with tuft of hair in front. Forewing with the costa arched, the apex produced and acute; vein 3 from before angle of cell ; 4, 5 from angle ; the discocellulars slightly curved; vein 6 from upper angle ; 7, 8, 9, 10 stalked in male, 7 from before 9 , in female vein 10 from the cell; 11 from cell ; the male with large glandular swelling at base of costa on underside fringed with oblique hair met by a tuft of long hair from median nervure. Hindwing with the cell short; vein 3 from angle ; 4, 5 shortly stalked ; the discocellulars angled ; 6,7 stalked, 7 anastomosing slightly with 8 .

\section{* Omphalophora rubrella.}

Omphalophora rubrella Hmpsn., Rom. Mém. viii. p. 428. pl. 53 . f. 13 (1901). Acara dohrni Hering, Stett. ent. Zeit. lxiv. p. 87. pl. 1. f. 34 (1903).

Sumatra; Java. 
GEN. Galleria.

Galleria Fabr., Ent. Syst. Suppl. p. 462 (1798) .

Cerioclepta Sodof., Bull. Nat. Mosc. x. 6. p. 20 (1837).

Vindama Wlk., xxxv. 1706 (1866)

Proboscis slight; palpi of male short, obliquely upturned, thickly scaled, of female downcurved and extending about the length of head ; maxillary palpi dilated with scales; frons with large tuft of hair; antennae of male almost simple, the basal joint somewhat dilated and with a tuft of scales below. Forewing with the costa slightly arched, the apex rounded, the termen excised to vein 2 , strongly in male, the tornus obliquely excised; the male with the cell about three-fourths length of wing; veins $2,3,4,5$ given off at even distances ; the discocellulars slightly angled inwards ; vein 6 from upper angle; $7,8,9$ stalked from before angle, 7 from beyond $9 ; 10,11$ from cell ; a small glandular swelling at base of costa on underside and the cell clothed with androconia; the female with the cell about two-thirds length of wing and veins 4,5 from angle. Hindwing with vein 3 from close to angle of cell; 4,5 stalked; the discocellulars angled inwards to about one-fourth from base; 6,7 stalked, 7 anastomosing with 8 .

\section{Galleria mellonella.}

Tinea mellonella Linn., Syst. Nat. edit. x. p. 537 (1758) ; Curt., Brit. Ent. xiii. p. 587 ; Hmpsn.,

Moths Ind. iv. p. 9; Rag., Rom. Mém. viii. p. 448 ; Staud., Cat. Lep. pal. ii. p. 2.

Tinea cereana Linn., Syst. Nat. edit. xii. p. 874 (1767).

Tinea cerella Fabr., Syst. Ent. p. 655 (1775).

Galleria cerea Haw., Lep. Brit. p. 392 (1811).

Vindana obliquella Wlk., xxxv. 1706 (1866).

Galleria austrina Feld., Reis. Nov. pl. 137. f. 7 (1874).

Almost universally distributed.

Type, G. mellonidiella.

Gen. Galleristhenia nov.

Proboscis fully developed; palpi of male porrect, extending about twice the length of head and thickly scaled above and below; maxillary palpi triangularly scaled; frons oblique; antennae short, simple. Forewing with veins 3 and 5 from close to angle of cell; 6 from below upper angle; 7 from angle ; 8,9 stalked; 10,11 from cell ; the wing narrow, the termen erect from apex to vein 3 where it is strongly hooked then very oblique. Hindwing with vein 3 from near angle of cell ; 4, 5 from angle which is greatly produced ; 6,7 from upper angle; 8 approximated to 7 beyond the cell; the termen slightly excurved at middle.

* Galleristhenia mellonidiella n. sp.

๙. Head and thorax pale red-brown; abdomen brownish white. Forewing pale red-brown suffused with grey and irrorated with a few dark scales; a postmedial line obsolescent towards costa, angled at vein 5 , then very oblique and formed of dark red-brown spots; cilia dark red-brown, whitish at tips below the hook. Hindwing semihyaline white; the costal area, termen, and base of cilia brown.

Queensland, Dawson district (Barnard), 1 oै type in coll. Rothschild. Exp. 46 mill. 


\section{Gen. Paraphycita.}

Paraphycita Hmpsn., Rom. Mém. viii. p. 451 (1901) . . . . . . epipercciella

Proboscis fully developed; palpi of female upturned, the second joint reaching to vertex of head and rather broadly scaled in front, the third long, roughly scaled in front; maxillary palpi long and filiform; frons smocth, the vertex of head with tufts of scales; antennae of female almost simple, the basal joint rather long. Forewing long and narrow, the apex rounded, the termen erect; the cell about two-thirds length of wing; vein 3 from angle ; 4,5 stalked; 6 from upper angle; 7, 8, 9, 10 stalked, 7 from beyond $9 ; 11$ from cell. Hindwing with vein 2 from close to angle of cell; veins $3,4,5$ stalked; the discocellulars curved; veins 6,7 from upper angle, 7 anastomosing with 8 .

\section{Paraphycita epipercciella.}

Paraphycita epiperckiella Hmpsn., Rom. Mém. viii. p. 451. pl. 53. f. 9 (1901).

Timor, Dili I., Oinainissa I.

\section{GEN. Megarthria.}

Megarthria Hmpsn., J. Bomb. Nat. Hist. Soc. xii. p. 304 (1899) . . . . . . velutinella

Proboscis short; palpi with the second joint porrect, extending about twice the length of head and moderately fringed with hair above and below, the third short, oblique, roughly scaled; maxillary palpi filiform; frons smooth with slight ridge of hair above ; antennae of male ciliated, the basal joint very long and curved. Forewing with the costa slightly arched, the apex rounded, the termen evenly curved; veins 3 and 5 from near angle of cell ; the discocellulars curved; 6 from upper angle; $7,8,9$ stalked, 7 from before $9 ; 10,11$ from cell; the male with glandular swelling at base of costa on underside fringed with hair met by an oblique fringe from median nervure. Hindwing with the cell rather short; veins $3,4,5$ from angle; the discocellulars angled; veins 6, 7 shortly stalked, 7 slightly anastomosing with 8 .

\section{Megarthria velutinella.}

Embryoglossa variegata Warr., A. M. N. H. (6). xviii. p. 226 (1896) ô, nec q.

Megarthria velutinella Hmpsn., J. Bomb. Nat. Hist. Soc. xii. p. 304 (1899); id., Rom. Mém. vii, p. 426. pl. 53. f. 12 .

\section{Sikhim ; Assam.}

\section{Gen. Embryoglossa.}

Embryoglossa Warr., A. M. N. H. (6). xviii. p. 225 (1896) .

Type.

Proboscis small; palpi porrect, the second joint extending about twice the length of head and fringed with hair above and below, the third rather long and smoothly scaled; maxillary palpi filiform; frons smooth, with ridge of hair above; antennae of male minutely serrate and with long fasciculate cilia, the basal joint with large tuft of hair in front, of female with shorter cilia; the back of head with tufts of hair. Forewing with the costa slightly arched, the apex rounded, the termen evenly curved; veins 3 and 5 from near angle of cell ; the discocellulars curved; 6 from upper angle; $7,8,9$ stalked; 10,11 from cell. Hindwing with vein 3 from near angle of cell ; 4, 5 from angle; the discocellulars curved; 6, 7 shortly stalked, 7 not anastomosing with 8 . 


\section{(1) Embryoglossa variegata.}

Embryoglossa variegata Warr., A. M. N. H. (6). xviii. p. 226 (1896); Hmpsn., Rom. Mém. viii. p. 424. pl. 53. f. 8 .

Assam.

(2) Embryoglossa bipuncta.

Embryoglossa bipuncta Hmpsn., J. Bomb. Nat. Hist. Soc. xiv. p. 658 (1901).

Assam.

GEN. Sphinctocera.

Sphinctocera Warr., Nov. Zool. iv. p. 128 (1897).

Type.

crassisquama

Proboscis rather short; palpi downeurved, extending about three times length of head and fringed with hair below; maxillary palpi filiform ; frons with large tuft of hair; antennae of male laminate with a small tooth above at one-fifth length, the basal joint long. Forewing with the costa slightly excised beyond middle, the apex rounded, the termen evenly curved; vein 3 from before angle of cell ; 4, 5 from angle; the discocellulars curved ; 6 from upper angle or stalked with $7,8,9 ; 7$ from before $9 ; 10,11$ from cell. Hindwing with vein 3 from close to angle of cell ; 4, 5 from angle or shortly stalked; the discocellulars curved; veins 6,7 shortly stalked, 7 slightly anastomosing with 8 or free.

\section{Sphinctocera crassisquama.}

Sphinctocera crassisquama Warr., Nov. Zool. iv. p. 128 (1897) ; Hmpsn., Rom. Mém. viii. p. 425. pl. 53. f. 16.

Transvaal; Natal; Cape Colony.

\section{Gen. Archigalleria.}

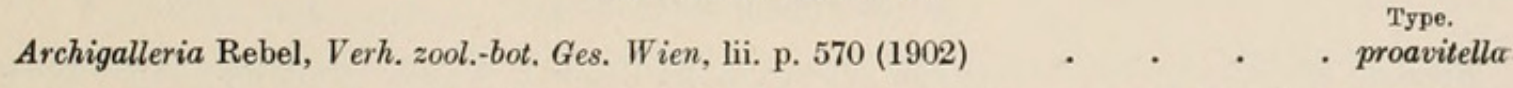

Proboscis rather short; palpi of male short, upturned, thickly scaled, of female downcurved, extending about three times length of head and smoothly scaled; maxillary palpi dilated with scales; frons with conical prominence produced to a slight corneous point at extremity; antennae of male almost simple, the basal joint somewhat dilated. Forewing with the costa moderately arched, the apex rounded, the termen evenly curved; the cell in both sexes about two-thirds length of wing; vein 3 from well before angle; 4,5 from angle ; 6 from upper angle ; 7,8 stalked, 9 absent ; 10,11 from cell, 10 approximated to 7,8 at base; the male with slight glandular swelling at base of costa on underside. Hindwing with vein 3 from close to angle of cell ; 4, 5 closely approximated for about half their length ; the discocellulars moderately angled inwards; 6,7 shortly stalked, 7 not anastomosing with 8 .

\section{Archigalleria proavitella.}

Aphomia proavitella Rebel, Ann. Hofmus. Wien, vii. p. 262 (1892) ; Staud., Cat. Lep. pal. ii. p. 2.

Canary Is. 


\section{Gen. Morpheis.}

Morpheis Hübn., Vers. p. 196 (1827). preocc. Bot. nec Zool.

Type.

Myelobia Herr. Schäff, Ausser. eur. Schmett. pp. 79. 75 (1858)

Proboscis fully developed; palpi in both sexes obliquely upturned, extending to the extremity of the frontal prominence and thickly scaled; maxillary palpi two-jointed, as long as the labial palpi and thickly scaled; frons with large conical prominence ending in a small corneous beak; antennae of male typically bipectinate with short branches to one-third length, then minutely serrate, of female with very short branches on basal third; tibiae rather strongly fringed with hair. Forewing long and narrow, the costa highly arched towards apex which is produced and somewhat falcate, the termen obliquely curved, the inner margin rather lobed towards base; vein 3 from well before angle of cell ; 5 from just above angle; the discocellulars angled; 6 from below upper angle ; 7 from angle ; 8,9 stalked ; 10,11 from cell ; veins 9 to 12 becoming coincident below the costa; the cell on underside clothed with rough downturned hair. Hindwing with the termen excised above tornus; vein 3 from near angle of cell ; 4, 5 shortly stalked or from angle; the discocellulars angled ; 6, 7 from upper angle, 7 free or slightly anastomosing with 8 .

Sect. I. Antennae in both sexes bipectinate with short branches towards base.

(1) * Morpheis pustulata.

Morpheis pustulata Herr. Schäff, Ausser. eur. Schmett. p. 75. f. 152 (1858), ઠ̛ ; Hmpsn., Rom. Mém. viii. p. 423.

Morpheis murina Herr. Schäff, Ausser. eur. Schmett. p. 75. f. 153 (1858), ‥

Brazil.

(2) Morpheis smerintha.

Morpheis smerintha Hübn., Samml. exot. Schmett. ii. pl. 195. ff. 3.4 (1821) ; Hmpsn., Rom. Mém. viii. p. 423. pl. 54. f. 16.

Mexico, Yucatan; Brazil (some specimens taken at sea 130 to 500 miles from land), Rio Grand do Sul.

(3) * Morpheis paleacea.

Morpheis paleacea Herr. Schäff, Ausser. eur. Schmett. p. 75. f. 150 (1858) ; Hmpsn., Rom. Mém. viii. p. 423.

Venezuela ; Brazil.

Sect. II. Antennae of male minutely serrate and fasciculate to base, of female ciliated.

\section{(4) Morpheis decolorata.}

Morpheis decolorata Herr. Schäff, Ausser, eur. Schmett. p. 75. f. 151 (1858); Hmpsn., Rom. Mém. viii. p. 424 . pl. 54. f. 5. 
Type, S. striata.

\section{GEN. Schoenobiodes nov.}

Proboscis aborted and small; palpi oblique, rather roughly scaled and reaching to about vertex of head; maxillary palpi nearly filiform; frons with rounded prominence; antennae of female almost simple, with tuft of scales on basal joint; anal tuft rather large. Forewing narrow, the costa arched, the apex produced and acute, the termen obliquely curved; the cell about twothirds length of wing; vein 3 from well before angle; 4.5 from angle ; the discocellulars angled ; 6,7 strongly stalked from below upper angle ; 8, 9, 10 stalked ; 11 from cell. Hindwing with vein 3 from before angle of cell ; 4, 5 from angle ; the discocellulars angled ; 6,7 from upper angle, 7 strongly anastomosing with 8 .

\section{Schoenobiodes striata.}

Acara striata Schultz, Phil. Journ. Sci. ii. p. 368. pl. 1. f. 11 (1907).

Philippines, Manila.

\section{Gen. Balaenifrons.}

Balaenifrons Hmpsn., Moths Ind. iv. p. 9 (1896) . . . . . . . homopteridia

Proboscis short arising with the filiform two-jointed maxillary palpi from the enormous conical smoothly scaled frontal prominence, which is grooved below, well in front of the labial palpi which are upturned in front of the prominence and smoothly scaled; antennae of male almost simple. Forewing with the costa arched, the apex rounded, the termen evenly curved; vein 3 from well before angle of cell; 5 from just above angle; the discocellulars curved; 6 from below upper angle; 7 from angle; 8,9 stalked; 10,11 from cell, the latter curved. Hindwing with the lower end of cell produced; veins $3,4,5$ well separated; the discocellulars angled; 6,7 stalked, 7 connected with 8 by an oblique bar; the retinaculum bar-shaped in male, the frenulum of female single.

\section{(1) † Balaenifrons haematographa n. sp.}

§. Golden yellow; head, thorax and abdomen with crimson mixed; palpi tinged with fuscous. Forewing with five ill-defined waved crimson lines with black marks suffused with silvery scales on them at costa except the subterminal line; the antemedial and medial lines confluent in the cell, the postmedial line incurved at discal fold and bent inwards below vein 3 , the subterminal line bent outwards to the margin and interrupted at vein 3. Hindwing semihyaline ochreous, the terminal area suffused with brown with a purplish crimson patch on it below vein 3 with two yellow marks on it at vein 2 .

․ Forewing without the black marks on the lines at costa ; hindwing with the terminal area suffused with crimson except towards tornus.

Solomon Is., Bougainville I. (Meek), 2 t type; Queensland, Cedar Bay, Cooktown (Meek), 1 으, Geraldton (Meek), ô, 우 in coll. Rothschild. Exp. ơ 22, 우 28 mill. 
(2) † Balaenifrons aryrostrota n. sp.

o. Head, thorax and abdomen golden yellow mixed with crimson-red; palpi yellow towards base, then red ; pectus, legs and ventral surface of abdomen white, the fore tibiae yellow banded with red. Forewing golden yellow with five ill-defined waved crimson-red bands suffused with silvery purple, the antemedial and medial bands confluent except towards costa and inner margin and the postmedial and subterminal bands confluent in places; a red discoidal striga. Hindwing yellow; some crimson-red on vein 2 near base; the apical area suffused with brown ; partly confluent postmedial and subterminal crimsonred bands suffused with silvery purple between discal and submedian folds. 16 mill.

Ceylon, Gampola (Green), 1 ô, Newera Eliya (Green), 1 ô type. Exp.

\section{(3) † Balaenifrons phoenicozona n. sp.}

Head and thorax yellowish white mixed with rufous; abdomen white with dorsal rufous bands towards base and dark brown bands towards extremity ; antennae yellow ringed with black-brown; pectus, legs and ventral surface of abdomen white, the fore femora blackish above, the fore and mid tibiae yellow and red with black bands at extremities and on the tarsi. Forewing golden yellow with deep red bands suffused with silver, their edges rather diffused; a subbasal band with black and silvery mark at costa; a black and silvery mark on costa near middle with the antemedial and medial bands arising from it and confluent to above inner margin where they fork; a black and silvery mark on costa above end of cell and two red discoidal points ; the postmedial band with black and silvery mark at costa, and partly confluent with a terminal band ending at vein 3. Hindwing semihyaline yellow; a red mark on vein 2 at its middle; the terminal area suffused with brown, a red and purplish silver patch on it below vein 3 with a small yellow spot on it at vein 2 .

Queensland, Cedar Bay, Cooktown (Meek), 1 ot type, ô, of in coll. Rothschild. Exp. 16 mill.

(4) Balaenifrons homopteridia.

$\dagger$ Balaenifrons homopteridia Hmpsn., Moths Ind. iv. p. 9 (1896); id., Rom. Mém. viii. p. 421. pl. 53. f. 4.

\section{Bengal ; Burma ; N. Borneo.}

(5) † Balaenifrons ochrochroa n. sp.

$\hat{o}$. Head and thorax ochreous mixed with brick-red; abdomen ochreous with a fulvous yellow band near base and some red suffusion toward extremity ; pectus, legs and ventral surface of abdomen ochreous white, the tibiae and tarsi suffused with rufous. Forewing ochreous thickly irrorated with brick-red; an oblique diffused red antemedial line; a discoidal spot; a diffused postmedial line, slightly incurved below vein 4; a fine dark terminal line; cilia ochreous white. Hindwing ochreous whitish suffused with brown, the cilia ochreous white.

Singapore (Wood-Jones), 1 ô type. Exp. 28 mill.

\section{Genera auctorum.}

Hombergia unicolor de Joan, Bull. Soc. Ent. Fr. 1910. p. 270, probably near Archigalleria. France. 

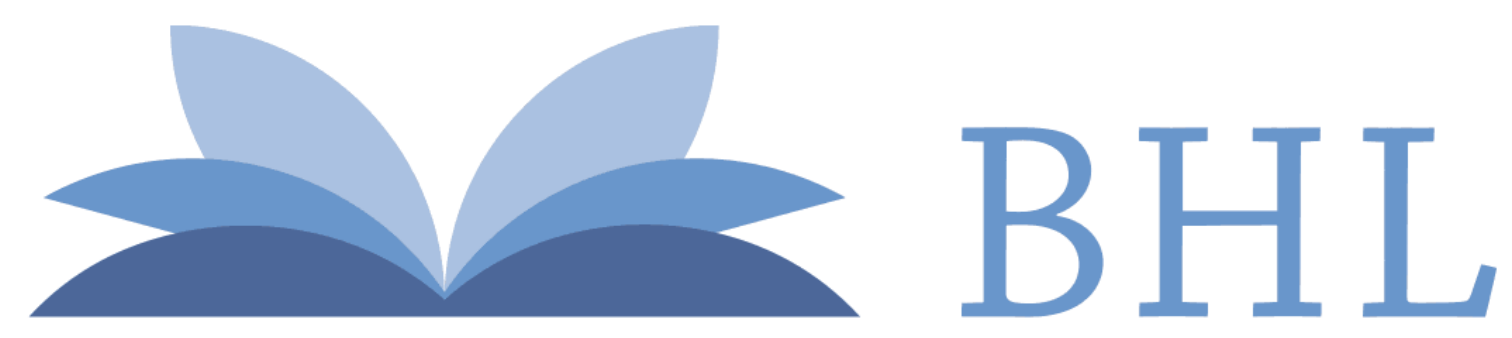

\section{Biodiversity Heritage Library}

Hampson, George Francis. 1917. "A classification of the Pyralidae, subfamily Gallerianae." Novitates zoologicae : a journal of zoology in connection with the Tring Museum 24, 17-58. https://doi.org/10.5962/bhl.part.23146.

View This Item Online: https://www.biodiversitylibrary.org/item/22361

DOI: $\underline{\text { https://doi.org/10.5962/bhl.part.23146 }}$

Permalink: https://www.biodiversitylibrary.org/partpdf/23146

\section{Holding Institution}

Natural History Museum Library, London

\section{Sponsored by}

Natural History Museum Library, London

\section{Copyright \& Reuse}

Copyright Status: Public domain. The BHL considers that this work is no longer under copyright protection.

This document was created from content at the Biodiversity Heritage Library, the world's largest open access digital library for biodiversity literature and archives. Visit BHL at https://www.biodiversitylibrary.org. 